Reprod. Nutr. Dévelop., 1986, 26 (5 A), 1025-1055.

\title{
Control of gene expression by steroid hormones
}

D. BÉCHET (1)

Meat Research Institute, Langford, Bristol BS18 7DY, England

Summary. The mechanism of action of steroid hormones involves their interaction with tissue-specific binding sites, and results in a precise modulation of gene expression. Both high-affinity receptors and secondary binding sites exist for steroid hormones in target tissues. Only steroid-receptor complexes were, in several cases, clearly shown to directly regulate transcription by interacting with DNA region(s) close to steroid-controlled genes. However other indications suggest that steroid hormones could also modulate transcription by altering chromatin conformation. These modifications encompass post-traductional modifications of histones and non-histone proteins, as well as changes in the pattern of histone variants. Beside transcription, there are also evidences that steroid hormones car modulate gene expression by regulating some RNA processing events. Whether highaffinity receptors or secondary binding sites directly regulate these events is not known. These observations however suggest that several levels of control might exist for steroid hormones to precisely regulate gene expression.

\section{Introduction}

\section{Steroid binding sites}

A. - High affinity receptors (Type I)

1. - Binding of steroids to untransformed receptors

2. - Cellular localization of steroid receptors

3. - Transformation of the steroid-receptor complex into a nuclear binding state

B. - Low affinity binding sites (Type II)

\section{Steroidal control of transcription}

A. - General organization of chromatin

B. - Characterization of active chromatin

(1) Present address : I.N.R.A. Theix, 63122 Ceyrat, France. 
C. - DNA signals for transcription

D. - Interaction of steroid-receptors with enhancer-like DNA sequences

E. - Steroidal control of chromatin organization

1. - DNA methylation

2. - Alteration of nucleosome structure

3. - Involvement of non-histone proteins

\section{Steroidal control of the processing of the transcript}

A. - RNA processing

1. - Capping

2. - Polyadenylation

3. - Splicing

4. - RNA stability

5. - Nucleocytoplasmic transport of RNA

B. - Ribonucleoprotein complexes and higher order structures

C. - RNP processing and steroid hormones

\section{Conclusions}

\section{Introduction}

Steroids can be divided into several major classes, e.g. progestins, androgens, oestrogens, glucocorticoids, yet they share a common general mechanism of action. The lipophilic non-ionic character of steroid hormones allows them to be transported, mainly by simple diffusion across cytoplasmic membranes (Müller et al., 1979). Although, in some instances, steroid binding proteins do exist within cell membranes (Giorgi, 1976 ; Pietras and Szego, 1977 ; Sadler and Maller, 1982), extracellular plasma carriers, together with intracellular binding sites, are generally considered the most effective regulators of cellular hormone levels (Giorgi, 1980). Once inside the cell, steroids can interact with a number of low affinity binding sites and eventually become metabolized by specific enzymes. Besides cytosolic steroid metabolism per se, steroid hormones might eventually modulate post-transcriptional processes (Liang et al., 1977 ; Whelly and Barker, 1982 ; Cochrane and Deeley, 1984). However, the selective action of steroid hormones on a large variety of tissue-specific metabolic processes is mainly dependent on the presence of tissue-specific high-affinity receptors (Type I) or other binding sites (Type II) exhibiting lower affinity but larger capacity for steroids. Interactions of steroids with these binders allow them to control gene expression. In this article, after briefly summarizing an exponentially growing documentation on tissue-specific receptors and other binding sites, we have emphasized the important role the macromolecular organization of eukaryotic nuclei is likely to play for steroids to regulate gene 
expression. Finally, our scope is to underline that multiple mechanisms of control might be involved for a precise modulation of gene expression by steroid hormones. Several excellent reviews, dealing in more detail with the binding properties of steroid receptors (Schmidt and Litwack, 1982 ; Housley et al., 1984), or with DNA recognition sites for steroid-receptors (Groner et al., 1984) were presented previously.

\section{Steroid binding sites}

\section{A. - High affinity receptors (Type I).}

Type I steroid receptors are characterized by a high affinity and a strict selectivity for a defined class of steroid hormones. Specific (Type I) receptors have been documented in a variety of tissues and for numerous species. Their presence is not confined to sex-related target tissues, as specific receptors are also present in liver (Eisenfeld et al, 1980 ; Tamulevicius et al., 1982 ; Bechet et al., 1983, 1986b) and muscle (Michel and Beaulieu, 1980 ; Dahlberg et al., 1981 ; Bechet et al., 1986a).

cDNA clones for mRNA encoding receptors for glucocorticoids (Miesfeld et al., 1985 ; Weinberger et al. 1985) and for oestrogen (Walter et al., 1985) have recently been isolated and the corresponding sequence of glucocorticoid receptor (Hollenberg et al., 1985) and oestrogen receptor (Green et al., 1986) have now been reported. Such data are likely to be determinant for a better understanding of the mechanisms of steroid binding and receptor activation and transformation.

\section{1. - Binding of steroids to untransformed receptors.}

Several lines of evidence suggest that in the absence of steroid, unoccupied steroid receptors are present in different conformations, which differ in their ability to bind hormones (for review see: Schmidt and Litwack, 1982; Housley et al., 1984). Some exist in an active binding state, others are unable to recognize their specific ligand. Transition to the active configuration(s) is believed to involve energy-dependent processes, such as sulfur reduction(s) or phosphorylation(s), in addition to other "endogenous factors " (Cake et al., 1976 ; Sato et al., 1980 ; Leach et al., 1982).

The cellular compartment(s) involved in steroid receptor inactivation is (are) not clearly defined. Receptor " inactivating activity " has been related to cellular membranes (Nielsen et al., 1977), crude nuclear pellets (Auricchio and Migliaccio, 1980 ; Auricchio et al., 1981a) and cytosol preparations (Sando et al., 1979b). At least, some of the "inactivating activity " is insensitive to protease inhibitors (Nielsen et al., 1977; Auricchio and Migliaccio, 1980). An ATP-dependent " reactivating activity" has also been partially purified from cytosol (Auricchio et al., 1981b). 
The bulk of the evidence supporting the view that some of these reactivatinginactivating entities involve a phosphorylation-dephosphorylation process, relies essentially on the demonstration that receptors for progesterone (Weigel et al., 1981 ; Dougherty et al., 1982), dexamethasone (Housley and Pratt, 1983 ; Singh and Moudgil, 1985) and oestradiol (Auricchio et al., 1984) are phosphoproteins. In fact, part of the stabilizing effects initially ascribed to the phosphatase inhibitor, sodium molybdate (Sando et al., 1979a ; Auricchio et al., 1981a), was recently more satisfactorily explained as direct interaction with the untransformed receptor (Grody et al., 1980; Housley et al., 1984). Thus $\mathrm{MoO}_{4}^{2-}$ is capable of forming phosphomolybdate or sulfhydrylmolybdate complexes, which could prevent an irreversible loss of binding capacity (Housley et al., 1984). An endogenous "stabilizing factor ", detected in cytosol preparations, shares many properties with $\mathrm{MoO}_{4}^{2-}$ (Cake et al., 1976, 1978 ; DiSorbo et al., 1980 ; Leach et al., 1982). In vivo this factor could stabilize the untransformed receptor and inhibit transformation of the receptor to the nuclear binding form (Sato et al., 1980 ; Leach et al., 1982 ; Housley et al., 1984).

The second component which has pronounced effects on the steroid-binding capacity of untransformed receptors appears to be a reducing environment. In the absence of reducing agents (e.g. DTT), binding capacity is reversibly lost, even in the presence of $\mathrm{MoO}_{4}^{2-}$. In some systems, such as rat liver cytosol, the " DTT effect " is hardly observed, due to high endogenous reducing activity (Leach et al., 1982). Recent reports have tentatively identified NADPH-dependent thioredoxin as the endogenous "activating factor " which, by maintaining a reducing environment, would favour binding of steroid to the receptor (Grippo et al., 1983, 1985 ; Housley et al., 1984).

\section{2. - Cellular localization of steroid receptors.}

The cellular location of steroid receptors is at the moment, subject to some controversy (see Szego and Pietras, 1985). After decades of steroid research, the " two-step hypothesis" (Jensen et al., 1968) emerged to become a dogma : receptors were cytoplasmic proteins which, upon binding to the steroid, were transformed into an " activated state " and then translocated to the nucleus. Recently, two approaches have, however, suggested an exclusive localization of oestradiol receptors in the cell nucleus, even without hormonal pretreatment. Greene \& collaborators (King and Greene, 1984), using several monoclonal antibodies to oestrogen receptor, observed only nuclear immunoreactivity in a variety of target tissues. Welshons et al. (1984) adopted a different strategy and employed cytochalasin B to prepare enucleated cytoplasts. They also concluded that oestrogen receptors were purely nuclear entities. A compromise has already been proposed by Sheridan et al. (1979) who suggested that distribution of unbound receptors between cytoplasm and nucleus was determined by the water content of these compartments.

Obviously, only more data, relating steroid receptors to the dynamic processes of the cell, will resolve the issue of the "two-step hypothesis ". 
Nevertheless, from wherever in the cell the untransformed receptor originates, there is general agreement on its reduced affinity for nuclei. In vivo, only the specific binding of a steroid to its receptor induces "transformation " of the steroid-receptor complex. Only this transformed complex binds avidly to nuclear structures, and is able to modify genetic expression. How transformation occurs is discussed in the next section.

\section{3. - Transformation of the steroid-receptor complex into a nuclear binding state.}

Cytoplasm and nucleus are inter-dependent and differentiate together. As all nuclear proteins are likely to be of cytoplasmic origin, the cytoplasm is potentially able to " reprogram " the nucleus, or at least to regulate nuclear functions. A selective localization of cytoplasmic and nuclear proteins requires an effective process to control the nucleocytoplasmic translocation of proteins to or from the nucleus. Transformation of steroid-receptors (Type I) might represent such a control mechanism. In conditions which exist in vivo, the steroid-receptor complex undergoes a rapid transformation to an "activated" (according to Litwack) or " transformed " (according to Pratt) state, characterized by its high affinity for nuclear structures (for review see: Schmidt and Litwack, 1982).

The transformation process can also be reproduced in vitro using various manipulations, such as high ionic strength, ammonium sulfate precipitation, elevated temperature, increased $\mathrm{pH}$, gel filtration or dilution (Milgrom et al., 1973 ; Redeuilh et al., 1981 ; Mac Donald and Leavitt, 1982 ; Bodine et al., 1984). The transformation of the steroid-receptor unit results in the exposure of positively charged regions on the surface of the complex (Milgrom et al., 1973). This activated complex is then characterized and distinguished from the untransformed receptor by its preferential binding to polyanions, such as DNA (Rousseau et al., 1975 ; Mac Donald and Leavitt, 1982), ATP-sepharose (Nishigori and Toft, 1980) or phosphocellulose (Mc Blain and Toft, 1983). Litwack and collaborators have developed a model according to which activation consists of both a dephosphorylation step and a step involving dissociation of an endogenous factor (the "stabilizing factor " of Pratt) from the untransformed steroid-receptor complex (Schmidt and Litwack, 1982).

No mechanism clearly details the subsequent nuclear processing or recycling of the receptor to the cytosol (Horwitz and Mc Guire, 1980).

\section{B. - Low affinity binding sites (Type II).}

Besides the classical high affinity receptors (Type I), other steroid-binding sites (Type 11), exhibiting lower affinity and specificity but higher capacity, occur in many tissues. Cytosolic Type II sites for oestrogens have been described in rat uterus (Clark et al., 1978), rat liver (Dickson et al., 1978), rat granulosa cells (Kudolo et al., 1984a, b), chick oviduct (Taylor and Smith, 1982a), and guinea pig seminal vesicles (Weinberger, 1984). Such heterogeneity in types of hormone 
binding sites is not limited to oestrogens and has also been observed for glucocorticoids (Barlow et al., 1979 ; Do et al., 1979) and progestins (Béchet and Perry, 1986).

Cytosolic Type II sites for oestrogens have been extensively studied in mature male rat liver (Dickson et al., 1978 ; Eagon et al., 1980 ; Miroshnichenko et al., 1983). The levels in cytosol of these macromolecules change in relation to endocrine status. For example, they disappear from cytosol after castration or after oestrogen treatment of male rats (Dickson et al., 1978 ; Eagon et al., 1980) and can be induced in female rat liver by administration of androgens (Smirnova et al., 1977, 1980).

There is no evidence that cytosolic Type II sites « translocate " to the nucleus (Eriksson et al., 1978 ; Mataradze et al., 1981 ; Taylor and Smith, 1982a ; Kudolo et al., 1984a), and there has been no shortage of suggestions for putative roles for these binding sites. They have been implicated in a precursor-product relationship with Type I receptors (Taylor and Smith, 1982a). A role of " sink » or "sponge ", protecting the cell against excesses of steroids has also been suggested (Dickson et al., 1978 ; Eagon et al., 1980). Alternatively, they might regulate the intracellular distribution and/or concentration of free steroid hormones (Kudolo et al., 1984b) or protect steroids from being rapidly inactivated (Taylor and Smith, 1982a).

While " translocation " has not been demonstrated, the presence of Type II binding sites in nuclei has been shown, at least in rat uterus (Eriksson et al., 1978; Clark and Markaverich, 1981) and rat liver (Béchet and Perry, 1986). Increasing interest in these nuclear Type II binding sites stems from two observations. First, though they do not seem to be translocated from the cytosol, they are induced, in some way, by hormonal pretreatment (Markaverich and Clark, 1979). Second, together with Type I sites, they do seem to play an important role in the events involved in oestrogen action (Markaverich and Clark, 1979 ; Markaverich et al., 1981 ; Clark and Markaverich, 1981). Hormonal manipulations have indicated that Type II sites are more closely correlated with true uterine growth than Type I sites which are only transient entities within nuclei (Markaverich and Clark, 1979).

In summary, all those observations suggest that a primary role of steroid hormones is, by binding to Type I receptors, to induce the transformation of steroid-receptor complexes to a " nucleophilic » form. Steroids might also induce nuclear Type II binding sites. Both the occurrence in situ of Type II sites, and the high affinity of transformed steroid-receptor (Type I) complexes for nuclear structures, imply role(s) in the regulation of gene expression. In this regard, several lines of evidences indicate that steroid hormones could not only control RNA polymerase-dependent transcription, but also regulate the processing of pre-RNA to mature RNA. 


\section{Steroidal control of transcription}

\section{A. - General organization of chromatin.}

The information which allows cells to differentiate or adapt to environmental stimuli is thought to be encoded in genomic DNA. Eukaryotic DNA is not found in discrete simple units. Genomic DNA, like most macromolecules, can undergo postsynthetic modifications. DNA is also packaged with histone proteins, and certainly interacts with many other nuclear constituents (specific proteins, RNP, nuclear skeleton,...). The occurrence of such complexes is not fortuitous, since eukaryotic gene expression takes place within a highly organized structure that allows specific genes to be recognized and properly phrased by relevant control systems. These must be as diversified or multifaceted as tissues can be specialized. In other words, accurate differentiation, tissue specificity and regulation of gene expression depend upon more complex "codes " superimposed on linear DNA sequences. The macromolecular organization of chromatin is therefore essential in determining what factors govern transcriptional activity, and particularly, how the same genetic code is differently expressed and controlled by steroid hormones in various tissues.

The basic unit for compaction of eukaryotic nuclear DNA is the " nucleosome core particle" which consists of 146 bp DNA coiled around a central protein core comprising one pair of each of the histones H2A, H2B, H3 and $\mathrm{H} 4$ (see Harauz and Ottensmeyer, 1985). With a further 20 bp of DNA adjoining the core, histone $\mathrm{H} 1$ seals two full turns of DNA around the histone octamer. This usual product of microccocal nuclease digestion is termed the " chromatosome ". The " nucleosome " contains an additional " linker " DNA which connects neighbouring core particles. This latter fragment of DNA varies in length between species, tissues or even within the same cell (Allan et al., 1980 ; Laskey and Earnshaw, 1980 ; Igo-Kemenes et al., 1982; Thomas, 1983). This " beads on a string " nucleosomal chain (equivalent to the thin $100 \AA$ fiber) provides the first level of chromatin organization. Further foldings of the chain generate higher levels of compaction, from thick $(250 \AA)$ fibers, to the loops or chromatin domains observed in interphase nuclei or metaphase chromosomes.

Thick fibers have been suggested as the basic structure for " inactive chromatin ", and histone $\mathrm{H} 1$ seems to be essential for their formation (Thoma et al., 1979 ; Thomas, 1984). Several characteristics of $\mathrm{H} 1$ might account for the dynamic properties of $250 \AA$ fibers. $\mathrm{H} 1$ on its own can form homopolymers (" clisones " of Mc Ghee and Felsenfeld, 1980), and exchanges rapidly between segments of chromatin, even at physiological $(0.1-0.2 \mathrm{M})$ ionic strength (Lasters et al., 1981 ; Caron and Thomas, 1981 ; Louters and Chalkley, 1985).

Higher orders of organization involve the compaction of thick fibers into domains of chromatin (Benyajati and Worcel, 1976). According to the " domain model " (Murray and Davies, 1979 ; Lepault et al., 1980), chromatin is precisely 
organized into loops, anchored to a proteinaceous scaffold commonly termed nuclear matrix or skeleton (for review see Pienta and Coffey, 1984). Loops may exist in extended or more compact conformations (Igo-Kemenes et al., 1982). Interest in such a model stems from proposals that at least some of these domains might be related to units of replication or transcription (Jackson et al., 1984). These proposals are substantiated by the demonstrations that a variety of functional components, including steroid-dependent transcribing genes (Ciejek et al., 1983 ; Jost and Seldran, 1984), newly synthesized and processed RNA (Herman et al., 1978), as well as sites of DNA replication (Pardoll et al., 1980 ; Tubo et al., 1985), are closely associated with the nuclear matrix.

\section{B. - Characterization of active chromatin.}

One obvious problem is how to explain the spatial architecture of active genes in relation to compacted inactive chromatin. Early observations pointed out that transcriptional activity was related to the chromatin decondensation (Pays and Flamand, 1976 ; Gottesfeld, 1977). Gene activation seemed to be linked with a conformational local relaxation in tightly-packed " inactive " chromatin. In agreement with these observations, nucleases appeared, as a rule, able to recognize some features of chromatin organization and degrade active genes more rapidly (Weintraub and Groudine, 1976 ; Levy and Dixon, 1978 ; Dimitriadis and Tata, 1980). The situation with respect to DNase $I$ is in particular, most interesting.

DNase I sensitivity extends far upstream and downstream from the coding region for a gene (Stalder et al., 1980a, b ; Bellard et al., 1980 ; Lawson et al., 1980 ; Storb et al., 1981). In addition, this nuclease does not simply distinguish actively transcribing genes, but also those genes which have been transcribed, or will be transcribed during some later stage of development (see review: Weisbrod, 1982). "Active genes ", defined by their sensitivity to DNase I, can thus be envisaged as lying in chromatin subunits or domains of "open " configuration, which seem to reflect more a potential for transcription than merely transcriptional activity (Mathis et al., 1980 ; Lawson et al., 1980 ; Stalder et al., 1980a, b).

Digestion of chromatin by DNase I under very mild condition allows also the characterization of hypersensitive sites at specific positions relative to the coding region of genes $(\mathrm{Wu}, 1980$; Groudine and Weintraub, 1981 ; Weintraub et al., 1981). The precise structural basis of DNase I hypersensitivity is still the subject of considerable debate, but there is growing evidence that at least some hypersensitive sites are related to sequences involved in regulating gene expression (Dean et al., 1983 ; Kaye et al., 1984 ; Fritton et al., 1984). Moreover, modulation of transcription may be governed by the binding of regulatory proteins to such hypersensitive regions (Emerson and Felsenfeld, $1984 ; \mathrm{Wu}, 1984 a, b$ ). In short, it appears that the precise macrostructural organization (or disorganization) of chromatin determines which genes are (potentially) active. This might be governed, for instance, by cell differentiation. Gene expression itself would 
require additional alterations of chromatin components, and/or interaction of regulatory factors with enhancer-like hypersensitive DNA sequences.

The molecular features which distinguish active from inactive chromatin have been the subject of numerous reports (Mathis et al., 1980 ; Igo-Kemenes et al., 1982 ; Weisbrod, 1982). They encompass post-synthetic modifications of DNA, histones and non-histone proteins. Yet, no single general molecular mechanism seems sufficient to account totally for hypersensitivity or transcriptional activity. As regards steroid hormones, there has been much emphasis on the presence of DNA recognition sites for high-affinity receptors, upstream from steroidcontrolled genes. However, other observations also consider steroid hormones as potential modulators of chromatin macrostructure.

\section{C. - DNA signals for transcription.}

The primary structure of eukaryotic DNA reveals important characteristics likely to be essential for an accurate and selective expression. Eukaryotic proteincoding genes are known to be split : the sequences (exons) coding for mRNA are interrupted by "non-coding " intervening sequences (or introns, IVS) and the entire split gene is transcribed into a precursor RNA (Abelson, 1979). The split gene phenomenon also applies to rRNA genes (Glover, 1983) and to tRNA genes (Clarkson, 1983 ; Peebles et al., 1983; Greer et al., 1983). In a protein-coding gene, each exon can be closely related to a functional or structural domain of the protein. Exons also appear well conserved through evolution. In contrast, introns have evolved rapidly, but can represent a major proportion of a gene (for review see : Breathnach and Chambon, 1981). Retention of the split-gene phenomenon may endow eukaryotes with selective advantages. By virtue of their IVS, eukaryotic genes might in theory have undergone many rearrangements throughout evolution.

A prerequisite for gene expression is the transcription $\left(5^{\prime}-3^{\prime}\right)$ of one DNA strand into a complementary RNA sequence. Distinct features allow DNA to be transcribed by the three different RNA polymerases. The nucleolar transcription of rRNA by RNA polymerase A (or I) involves a promoter lying between 320 nucleotides upstream and 113 nucleotides downstream from the DNA initiation site (Bakken et al., 1982 ; Grummt, 1982). Termination of rRNA transcription apparently requires a cluster of at least $3 T$ residues at the $3^{\prime}$ end of the transcription unit (Bakken et al., 1982). RNA polymerase $C$ (or III) transcribes genes coding for tRNA, 5S RNA and other small RNA (7S RNA, 7-3 RNA, La 4.5 RNA and $Y$ RNA) (Busch et al., 1982). Surprisingly, it appears that promoters for tRNA and 5S RNA genes are located within the genes themselves (Clarkson, 1983 ; Miller, 1983). RNA polymerase $B$ (or (1) transcribes those genes which code for mRNA as well as all capped small nuclear RNA, e.g. $\mathrm{snU}_{1}$ to $\mathrm{snU}_{6}$ (Busch et al., 1982). More information is available about RNA polymerase B-dependent transcription, and the subject has been extensively reviewed (Abelson, 1979 ; Breathnach and Chambon, 1981 ; Nevins, 1983). 
At least 2 regions have been delineated which are involved in intitiation by RNA polymerase B. (1) The "TATA box" (TATA $T_{T} A_{T}$ ) is located 25-35 nucleotides upstream from the start site. This sequence seems to be involved in accurate positioning of RNA polymerase $B$ molecules at the initiation site (Grosschedl and Birnstiel, 1980). (2) The "CAAT box » (GC C CAATCT), which is located about $70-80$ base pairs (bp) upstream from the initiation site, appears to modulate mRNA transcription (Grosschedl and Birnstiel, 1980). Deletion of these promoters does not however eliminate transcription and it has not yet been demonstrated that RNA polymerase $B$ binds to any of these sites. It seems that other sequences (enhancers), located far upstream from the actual start site, are also important for the initiation of transcription.

Although it is well established that initiation of transcription by RNA polymerase B occurs at the nucleotide corresponding to the $5^{\prime}$ end (cap site) of RNA (Breathnach and Chambon, 1981 ; Nevins, 1983), the sequence(s) specifying termination of transcription by RNA polymerase $B$ and the mechanism by which the RNA chain is released, remain unclear. A recognition signal (AATAAA, located 1030 bp upstream from the $3^{\prime}$ end) has been suggested to control RNA $3^{\prime}$ end polyadenylation (Proudfoot and Brownlee, 1976). However, transcription often terminates beyond the site of poly(A) addition and the RNA $3^{\prime}$ end seems in fact to be generated by RNA endonucleolytic cleavage rather thant by real transcriptional termination. Multiple poly(A) sites are known to occur in " complex transcription units " (Amara et al., 1982), and partial read-through across these sites can allow transcription of downstream exons. Such selection of a poly $(A)$ site, and therefore termination of transcription, is obviously one control mechanism of gene expression (Rozek and Davidson, 1983 ; Nevins, 1983).

\section{D. - Interaction of steroid-receptors with enhancer-like DNA sequences.}

DNA sequences (enhancers), which confer upon particular genes their sensitivity to inducers, tend to be located in the $5^{\prime}$-flanking region. Amongst the many regulators of gene expression, transformed steroid-receptor complexes $\left(R E^{*}\right)$ have been implicated in the control of transcription of steroid-dependent genes (Payvar et al., 1981 ; Govindan et al., 1982 ; Pfahl, 1982 ;Taylor and Smith, $1982 b, 1985)$. DNA sequences that preferentially bind $R^{*}$ were also shown to exist in regions upstream from the transcriptional start site for genes controlled by progesterone (Mulvihill et al., 1982 ; Compton et al., 1983), glucocorticoids (Karin et al., 1984 ; Scheidereit and Beato, 1984 ; Groner et al., 1984), oestrogens (Jost et al., 1984) and androgens (Davies, personnal communication). No preferential binding site for $\mathrm{RE}^{*}$ has yet been demonstrated in genes other than those which code for proteins. The biological role of receptor binding to DNA recognition sites is now clearly established. Hybrid genes were constructed and used to transfect target cells known to contain specific receptors for steroid. These gene transfer experiments indicate that the promoter region of a steroid-controlled gene, which also contains DNA binding site(s) for the steroid-receptor complex, can be sufficient to confer hormone inducibility on an heterologous gene to which it is 
linked in cis (Lee et al., 1981 ; Renkawitz et al., 1982 ; Dean et al., 1983). According to these observations, steroid-receptors would therefore control steroid-dependent gene by interacting with enhancer-like DNA sequences. The DNA binding sites can also be located far upstream from the initiation site (Cato et al., 1984), or even within introns of the transcription unit (Payvar et al., 1981 ; Moore et al., 1985). It has thus been conjectured that multiple receptor binding events might be required to alter chromatin structure across the entire transcription unit and increase transcription rates (Cato et al., 1984). Nevertheless, the interaction of steroidreceptor complexes with enhancer-like DNA regions does not seem always sufficient to confer hormone inducibility.

Recognition sites also exist in genes not regulated by steroid hormones, and, more importantly do not exist in other genes which are regulated by steroids. No DNA binding site for dexamethasone-receptor seems to exist in glucocorticoiddependent genes, such as rat growth hormone, rat uteroglobin or human proopiomelanocortin genes (see Moore et al., 1985; Perry and Béchet, unpublished data).

In chick oviduct, two types (A and B) of high affinity receptors exist for progesterone and both types of progesterone-receptor complex (Prog-receptor) translocate to nuclei (Schrader and O'Malley, 1978). DNA recognition sites were described upstream from progesterone-controlled genes, but only for progreceptor $A$. Prog-receptor $B$, in contrast, do not specifically interact with DNA, but preferentially bind to chromatin " acceptor sites » (Birnbaumer et al., 1981). The exact nature of the nuclear acceptor sites for Prog-receptor B is still an area of extensive investigation (Spelsberg et al., 1983). However, it would appear that progesterone-specific gene activity in chick oviduct is more closely correlated to the presence in nuclei of functional receptors $B$ than to the existence of nuclear receptors A (Boyd-Leinen et al., 1984).

Besides specific binding of steroids to high-affinity (Type I) receptors, there is additional evidence that cytosol and nuclei from various tissues contain other lower-affinity (Type II) binding sites for steroid hormones. In one instance, the importance of nuclear Type II sites in controlling rat uterine growth has been emphasized (Markaverich et al., 1981 ; Clark and Markaverich, 1981). Although the exact nature of these Type II binding sites is not known, it is interesting to note that their nuclear acceptor sites do not seem to be related to DNA (Clark and Markaverich, 1982 ; Simmen et al., 1984).

Therefore, in addition to steroid-receptors (Type I) interacting with enhancerlike DNA sequences, modulation of gene expression might also result from a steroidal regulation of chromatin macrostructure. This could involve, not only classical receptors, but also other low-affinity Type II steroid binding sites. In fact, any modification of DNA, or chromatin protein could alter chromatin organization and modulate transcriptional activity. 


\section{E. - Steroidal control of chromatin organization.}

\section{1. - DNA methylation.}

The most common modification of eukaryotic DNA is cytosine methylation, predominantly in the sequence $\mathrm{CpG}$, which occurs in opposite pairs in the DNA duplex (Doerfler, 1983). Interest in DNA methylation has arisen partly from its ability to be perpetuated in a cell population. 5-Methylcytosine is inherited in a semiconservative fashion during replication, with newly synthesized DNA being accurately methylated early post-replication (Burdon and Adams, 1969) by maintenance DNA methylase(s) (Adams et al., 1979). Nevertheless, the pattern of DNA methylation also evolves during tissue differentiation. Both de novo methylation of satellite DNA, as well as demethylation of specific active genes may occur during the course of development (Weintraub et al., 1981). Though demethylation could simply result from an inhibition of maintenance DNA methylase, the identification of separate demethylating activities (Gjerset and Martin, 1982) and of de novo DNA methylases (Sano and Sager, 1980; Adams et al., 1979) emphasize more the possible scope for modulators of gene expression in control of DNA methylation/demethylation. Indeed, in some cases, a strong relationship is seen to exist between undermethylation, tissue specificity, DNAse I sensitivity and transcriptional activity (Weintraub et al., 1981 ; Bird et al., 1981 ; Naveh-Many and Cedar, 1981). More precisely, the function of DNA methylation would depend mainly on a specific localization within or in the vicinity of regulatory sequences (Wilks et al., 1982; Busslinger et al., 1983; see also Doerfler, 1983).

One could argue that methylation (or demethylation) simply results from gene repression (or expression) on its own, and so is not regulatory. However two complementary mechanisms might account for a control of chromatin structure by DNA-methylation. First, double-stranded DNA (dsDNA) can assume different conformations, according to its environment, or as a result of specific DNA sequences. The classical $B$ form is stabilized by nucleosome particles. Methylation, however, seems to stabilize Z-DNA (Behe and Felsenfeld, 1981). Demethylation of this latter conformation might impose a torsional stress on the DNA duplex and result in some unwinding of the double helix. Such regions would then be potential sites for replication or transcription (Nordheim et al., 1981 ; Nordheim and Rich, 1983). Second, DNA methylation can alter DNAprotein interactions, and thereby directly control chromatin conformation and expression. The dependence upon either methylated on unmethylated DNA for specific restriction endonucleases to act (Hpall and Msal) exemplifies this point.

Relevant to these observations are the demonstrations that, in vitro, steroidreceptors are capable of protecting their DNA binding sites against methylation with dimethyl sulphate (Scheidereit and Beato, 1984; Karin et al., 1984). Methylation of the DNA site can also prevent binding of the receptor (Cato et al., 1984). In vivo, there is only limited information on whether the steroid-regulated demethylation of DNA results from or induces gene activity. In chicken liver, 
oestradiol controls the transcription of Vitellogenin II gene and also brings out a precise demethylation of the oestradiol-receptor binding regions upstream from liver Vitellogenin II gene (Wilks et al., 1982). In this case, demethylation occurs long after oestradiol induction of liver Vitellogenin and, therefore, seems only to result from transcriptional activity.

\section{2. - Alteration of nucleosome structure.}

It would be a very simple concept to imagine absence of nucleosome core particles as sufficient for transcriptional activity to proceed. Immunological (Scheer et al., 1979) and nuclease digestion studies (Garel and Axel, 1976) have confirmed the presence of core histones in transcribing gene regions. The lesser compaction of active chromatin, rather than core histone depletion, might therefore be a better explanation of unfolding of the polynucleosome filament. The presence of histone isoforms and/or postsynthetic modifications of histones could release constraints upon DNA strands, and thereby alter nucleosome structure and the conformation of chromatin.

Histone variants, differing by just a few amino acids from the classical histones are known to occur (Von Holt et al., 1979; Allis et al., 1982). They provide some evidence for species-, tissue-, and gene- specific characteristics (Benezra et al., 1981 ; Wu et al., 1982a). A role in cell differentiation (Von Holt et al., 1979) has been suggested by the occurrence of precisely-timed changes in histone subtypes during specific stages of development (Wu et al., 1982b). Interestingly, the glucocorticoid-induced synthesis of mouse mammary tumor virus RNA in GR cells is highly correlated with changes in the relative amount of $\mathrm{H} 1$ variants (Wurtz, 1985). Whether these modifications result from a direct control by receptor-like molecules is unknown at the moment, but they suggest that, in this case, by changing the pattern of histone variants, steroid hormones might have the potential to induce rearrangements in chromatin structure.

Of the numerous post synthetic modifications histones can undergo (phosphorylation, acetylation, methylation, poly(ADP) ribosylation,...), histone acetylation seems to particularly characterize actively transcribing chromatin (Vidali et al., 1978 ; Levy-Wilson et al., 1979a ; Malik et al., 1984). Acetylation of Lys residues occurs in all core histones, within the basic $\mathrm{NH}_{2}$-terminal region of the molecules, which also acts as the DNA-binding domain. Core histone acetylation might reduce their electrostatic interaction with DNA and so enhance DNA-template accessibility to RNA polymerase (Allfrey, 1982). Control of histone acetylation by steroid hormones has been referred to for oestradiol in target tissues, such as uterus (Libby, 1972 ; Pasqualini et al., 1981) or liver (Pasqualini et al., 1981), as well as for cortisol in rat liver (Graaf and Von Holt, 1973). Moreover, steroid-induced acetylation of histones is a very dynamic process $(10 \mathrm{~min}$; Pasqualini et al., 1981) which is well suited to a rapid regulation of gene expression.

Steroid receptors seem also capable of binding to core histone proteins. Kallos et al. (1981) have demonstrated, in vitro, preferential interactions between 
transformed oestradiol-receptor complex and histones $\mathrm{H} 2 \mathrm{~A}$ and $\mathrm{H} 2 \mathrm{~B}$. More data are obviously needed to clarify whether in vivo such phenomenons are relevant to the mode of action of steroid hormones. All these observation might, however, relate to processes whereby steroid-receptors could alter gene expression by means of controlled modifications of nucleosome conformation.

\section{3. - Involvement of non-histone proteins.}

Histones are certainly the best characterized DNA-binding proteins in eukaryotes, and their role as " packaging " proteins or non-specific repressors of gene expression is well established. SDS-polyacrylamide gel electrophoresis of "chromosomal proteins " also reveals an intricate and complicated pattern of non-histone proteins (NHP). High mobility group (HMG) proteins are NHP which have been extensively purified, characterized, and in some instances, specified as regulators of gene expression. HMG 1 (or 2) can unwind double-stranded DNA (Javaherian et al., 1978), probably as a result of their selective affinity for singlestranded DNA (Isackson et al., 1979). Such helix destabilizing properties have led to suggest possible involvement in DNA replication (Alexandrova et al., 1984) or transcription (Goodwin and Mathew, 1982).

Several studies have associated HMG 14 (or 17) with actively transcribing chromatin (Weisbrod and Weintraub, 1979 ; Levy-Wilson et al., 1979b). HMG 14 (17) seem able to recognize some structural characteristic(s) of chicken erythrocyte chromatin and, on binding to the region, induce DNAse I sensitivity (Weisbrod and Weintraub, 1979 ; Gazit et al., 1980). HMG 14 (17) are themselves subject to post-transcriptional modifications, such as acetylation-deacetylation or poly(ADP) ribosylation (Allfrey, 1982).

Interestingly, there is substantial evidence (Pasqualini et al., 1981 ; Allfrey, personal communication) that oestradiol administration can induce acetylation of HMG proteins in target tissues. Moreover, there are also indications that the glucocorticoid-induced RNA synthesis in mouse mammary tumor cells is concomitant with poly(ADP) ribosylation of HMG 14 (17) proteins (Tanuma et al., 1983). A control by steroid hormones of acetylation or poly(ADP) ribosylation of NHP such as HMG proteins could potentially result in modifications in chromatin conformation and gene accessibility to RNA polymerase.

Whether high-affinity receptors or low-affinity binding sites directly control post-synthetic modifications of DNA, histones, non-histone proteins or other constituents of chromatin remains unknown at the moment. Chromatin acceptor sites, other than DNA alone, have nevertheless been the subject of numerous reports (Perry and Lopez, 1978; Spelsberg and Halberg, 1980; Kon and Spelsberg, 1982 ; Ross and Ruh, 1984). The exact nature of the " acceptor proteins ", together with the mechanism by which they regulate expression of specific genes is still under extensive investigation (see Spelsberg et al., 1983). However, the acceptor proteins appear to exhibit tissue-specificity and to generate functional acceptor sites for steroid receptors only when bound to specific DNA sequences (Spelsberg et al., 1984; Toyoda et al., 1985). These observations would tend to suggest important functions in the control of gene 
expression, despite the fact that no enzymatic activity has yet been associated with acceptor proteins.

\section{Steroidal control of the processing of the transcript}

DNA-dependent transcription results in the synthesis of pre-RNA molecules comprising both exon and intron transcripts. These large precursors (hnRNA) must undergo several obligatory processing events, in order to generate mature RNA molecules. All post-transcriptional processes of pre-RNA are potential sites for primary regulation of genetic expression. They govern accurate RNA capping, polyadenylation, splicing and stabilization. Thus, they determine which transcript will be transported to the cytoplasm for eventual translation. Essential requirements for adequate RNA processing events are both specific signals in the RNA nucleotides sequence, and appropriate enzymatic and "packaging " systems. After briefly summarizing RNA processing events, we will try to emphasize the limited but, we believe, significant data which suggest that steroid hormones can also control gene expression via a modulation of RNA processing.

\section{A. - RNA processing.}

\section{1. - Capping.}

The formation of a $5^{\prime}$-cap structure is coupled to initiation of transcription by RNA polymerase II (Jove and Manley, 1982). The cap structure might be involved in protection of RNA against nucleolytic attack as well as be involved in RNA splicing events (Nevins, 1983).

\section{2. - Polyadenylation.}

Poly(A) addition to the pre-mRNA $3^{\prime}$ end occurs 11-19 nucleotides downstream from the consensus sequence AAUAAA. Recent reports (Gil and Proudfoot, 1984 ; see review by: Birnstiel et al., 1985) suggest that this hexanucleotide together with additional sequences act as recongnition sites for proper endonucleolytic cleavage of the nascent RNA chain. The new pre-mRNA $3^{\prime}$ end, so formed, is then the site of polyadenylation. $\operatorname{Poly}(A)$ addition is a rapid process and occurs very early on the nascent pre-mRNA chain (Salditt-Georgieff et al., 1980b; Nevins, 1983). Poly(A) polymerase has been identified immunologically (Rose et al., 1979) as the 75,000-Mr poly(A) binding protein (Roy et al., 1979). Pre-mRNA polyadenylation might also be directed by hybridization of the nascent RNA with small nuclear RNA $U_{4}\left(U_{4}\right.$ snRNA) (Berget, 1984) and/or U1 snRNA (Moore and Sharp, 1984). Other, yet unknown, components of the 
polyadenylation machinery might also be involved, in order to select the correct poly(A) addition site in complex transcriptional units (Nevins, 1983). There is evidence that the poly(A) tail determines the stability of RNA transcripts (Huez et al., 1981) and particularly of mRNA in cytoplasm (Zeevi et al., 1982).

\section{3. - Splicing.}

The splicing process ensures both excision of intron transcripts from the preRNA chain and accurate ligation of exon transcripts. Individual intron transcripts are excised from pre-RNA in several steps which have recently been described for protein-coding RNA (Konarska et al., 1985 ; Reed and Maniatis, 1985). First, the 5 '-splice site is cleaved and the $5^{\prime}$-end of the intron (a G-residue) forms a phosphodiester bond to a A-residue inside the same intron. This branch point is located 20-40 nucleotides upstream from the $3^{\prime}$-splice site. The second step involves the excision of the intron as a lariat form and the concomitant ligation of the two exons.

A part from involvement of RNA primary sequences, accuracy of splicing for the most part depends also on hnRNA-interactions with other RNA and specific proteins. Among RNA molecules which have been proposed to guide the splicing events are small nuclear RNA's (snRNA). Some exist hydrogen bonded to hnRNA (Gallinaro and Jacob, 1981 ; Zieve and Penman, 1981 ; Serekis and Guialis, 1981 ; Setyono and Pederson, 1984). Moreover, anti-snRNP antibodies have been demonstrated to inhibit hnRNA splicing (Yang et al., 1981). $U_{1}$ snRNA, especially, exhibits a 5'sequence strikingly complementary to the splice junction (Lerner et al., 1980 ; Rogers and Wall, 1980). These observations have led to the proposal that $U_{1}$ snRNA might hybridize to pre-mRNA and be involved in splicing of hnRNA (Gallinaro et al., 1981 ; Busch et al., 1982 ; Di Maria et al., 1985).

HnRNA and snRNA also exist in vivo as ribonucleoprotein particles (hnRNP and snRNP, respectively). It is thus important to consider tant splicing must occur within highly organized ribonucleoprotein multicomponents, somewhat analogous to ribosomes (Brody and Abelson, 1985 ; Grabowski et al., 1985 ; Frendewey and Keller, 1985).

\section{4. - RNA stability.}

Even with adequate mechanisms for RNA transcription, capping, polyadenylation or splicing, the delivery of mature RNA from nucleus into cytoplasm can also be affected by the relative stabilities of pre-, intermediate- or mature-RNA. In addition, expression of a particular gene will be more efficiently switched off by simultaneous repression of transcription with controlled degradation of pre-existing RNA. RNA processing events, such as 5'capping (Nevins, 1983) and poly(A) addition (Huez et al., 1981) have been suggested as protecting RNA against nucleolytic degradation. 


\section{5. - Nucleocytoplasmic transport of RNA.}

Mature RNA is then transported into cytoplasm through the nuclear pore complex (for a recent review see Clawson et al., 1985). The precise mechanism of transport remains unknown, but it does exhibit selectivity towards correctly processed mRNA (Webb et al., 1981) or rRNA (Wunderlich, 1981). Accurate splicing of pre-RNA to mature RNA is apparently a prerequisite for nucleocytoplasmic transport. RNA transport is also an energy-dependent process and involves a nucleoside triphosphatase associated with nuclear envelope and matrix (Clawson et al., 1985).

\section{B. - Ribonucleoprotein complexes and higher order structures.}

Nuclear RNA co-exists with specific proteins in highly complex macrostructures (hnRNP), whose architecture is somehow controlled by the nuclear skeleton (matrix). A simplified scheme is to imagine nascent RNA extending from transcriptionally active chromatin, itself looped-out from condensed heterochromatin (Sommerville, 1981; Vlad, 1983). Nascent transcripts are attached to the DNP axis by RNA polymerase molecules, and as transcription proceeds, newly-formed RNA arise as a gradient of fibrils of increasing length (Franke and Scheer, 1978 ; Puvion and Moyne, 1981). Specific proteins rapidly bind to nascent RNA immediately adjacent to RNA polymerase molecules (Sommerville, 1981). HnRNP fibrils are commonly observed as " $20-30 \mathrm{~nm}$ beads on a string ", somewhat analogous to nucleosomal DNP fibrils, and a major set of closely-related polypeptides is considered to generate and maintain this packaging of hnRNP (Leser et al., 1984 ; Choi and Dreyfuss, 1984 ; Wilk et al., 1985). Likewise, preribosomal structures are evident before transcription of rRNA precursor is completed (Glover, 1983).

Close observations indicate, however, other diverse configurations for nascent RNA, even along the length of a single transcript (Sommerville, 1981). Thus, superimposed on the simple "ribonucleosomal " model, more complex structures exist. In addition to specific protein-protein or protein-RNA interactions, RNA base-pairing can occur within the same molecule (Jelinek and Darnell, 1972 ; Jelinek et al., 1974 ; Kish and Pederson, 1977) or with other RNA (Brunel et al., 1981 ; Gallinaro et al., 1981 ; Setyono and Pederson, 1984). All these highly organized configurations of RNP might be expected to influence processing events. Certain snRNP seem to play a central role in splicing and poly (A) addition, if not most RNA processing events. The nuclear skeleton appears to support DNA replication (Pardoll et al., 1980 ; Tubo et al., 1985) and transcription (Robinson et al., 1983 ; Ciejek et al., 1983 ; Jost and Seldran, 1984) by tightly anchoring DNP. This structure also binds hnRNP (Herman et al., 1978 ; Miller et al., 1978a ; Van Eekelen and Van Venrooij, 1981) and snRNP (Miller et al., 1978b ; Gallinaro et al., 1983), as if it is equally involved in RNA processing events. Concerted transport and processing of nascent RNP to mature-RNP thus 
resemble an " assembly line », from the DNP transcriptional unit to the nuclear pore complex, where the role of the "conveyor belt " might be played by the nuclear matrix.

\section{C. - RNP processing and steroid hormones.}

In vitro, cytosolic steroid-receptor complexes not only bind to DNA, but also demonstrate significant interactions with RNA (Economidis and Rousseau, 1985). RNA is a potent competitor for the binding of receptor- androgen (Liao et al., 1980), -oestrogen (Feldman et al., 1981; Chong and Lippman, 1982), and -dexamethasone (Tymoczko et al., 1982) complexes to DNA-cellulose. Moreover, rRNA, tRNA and poly(A) RNA, all are capable of promoting release of receptor complexes that were bound to DNA in vitro (Liao et al., 1980). There is also some evidence that steroid-receptor complexes can interact in vitro with ribonucleoprotein particles isolated from uterine cytosol (Liang and Liao, 1974), as well as from prostate and uterine nuclei (Liao et al., 1973).

Selective recognition of RNA or RNP by steroid-receptor complexes might suggest a post-transcriptional role in RNA processing. Regulation of genetic expression by steroid hormones may not simply be due only to an interaction of receptor complexes with DNA regulatory regions or to modulation of the conformation of the DNP axis. RNA might compete with DNA for the polynucleotide binding site of the steroid receptor. A preferential binding of nuclear chicken oviduct oestrogen-receptor to poly(A) RNA was suggested by Lin and Ohno (1983). Such RNA-receptor interactions might be relevant to the reported stabilization of specific mRNA by steroid hormones. The half-life of ovalbumin mRNA was significantly reduced in oestrogen withdrawn chick oviduct (Palmiter and Carey, 1974 ; Cox, 1977) ; similarly, oestrogen or progesterone was demonstrated to affect the half-life of colnalbumin mRNA in chick oviduct (Mc Knight and Palmiter, 1979), and androgen to modulate the half-life of prostatic binding protein mRNAs (Page and Parker, 1982).

Many other roles for steroid-receptor complexes can be envisaged in RNA processing or transport. Direct evidences supporting the concept that oestradiol stimulates the nucleocytoplasmic transport of RNP in rat uterine nuclei were presented by Vazquez-Nin et al., (1978, 1979) and more recently by Thampan (1985). Furthermore, most interesting is that, when nuclear matrix fulfills the structural requirement for a conveyor belt for RNP processing and transport, oestrogen and androgen receptors have also been considered integral components of this skeleton (Barrack and Coffey, 1980 ; Béchet et al., 1986b). In this context, receptor-RNA interaction might not only be an important mediator of RNA processing and transport, but also a component of receptor processing and/or transport back to the "cytosol ». Recycling of nuclear steroid-receptors to their cytosolic form nevertheless remains an enigma (Horwitz and Mc Guire, 1980 ; Kasid et al., 1984), yet there is evidence that untransformed " cytosolic receptors " can exist complexed with RNA (Chong and Lippman, 1982 ; Tymoczko and Phillips, 1983 ; Economidis and Rousseau, 1985). 


\section{Conclusions}

Despite extensive scientific interest in steroids and anabolic agents, the exact mechanism(s) of action for these hormones at the sub-cellular level remain(s) to be elucidated. Steroid-receptor complex formation requires preliminary " activation » of the receptor to a binding state, and " translocation " to nuclei involves transformation of the steroid-receptor complex to a nucleophilic form. Only recently have observations began to clarify the molecular modifications and/or interactions with other factors that occur when receptors undergo the activation and transformation processes. In this development even basic principles, such as the "two step hypothesis", have become suspected as inaccurate, with the precise cellular location of untransformed steroid receptors in controversy.

Steroids are capable of modulating gene expression, and recently there has been considerable emphasis placed on the recognition, by transformed steroidreceptors, of specific DNA sequences upstream from steroid controlled genes. The postulate is that steroids modulate transcription by interacting, via highaffinity receptors, with enhancer-like DNA regions. However, the only recognition by steroid-receptors of enhancer-like DNA sequences do not explain why the same steroid receptor do not regulate the same gene within different target tissues. If we exclude a tissue-specific rearrangement of DNA control regions during differentiation, the primary structure of DNA is therefore insufficient to totally account for a transcriptional control by hormone-receptor complexes. In fact, eukaryotic DNA does not execute its functions as an isolated simple unit. Transcription requires decondensation of a highly organized complex of DNA with histones, non-histone and scaffold proteins. Many alterations of this macrostructure are possible which might result in enhanced DNA-template accessibility to RNA polymerases. Such additional codes superimposed on DNA primary structures are likely to determine which genes are (potentially) active. Substantial evidence also indicates that steroids might efficiently control gene expression via such modification in chromatin conformation.

In addition to DNA transcription, many other processes are also available as potential mechanisms of control over gene expression. Proper maturation and transport of pre-RNP to mature-RNP is essential. Steroid hormones have been shown to affect the stability of specific RNA, and to modulate RNA nucleocytoplasmic transport, if not other RNA processing events.

An alternative view to steroid-receptors acting as a specific key to a single lock might therefore be to consider steroid binders as capable of modulating different aspects of gene expression, from DNA transcription to RNA transport by acting as a "master" key to several locks. By this, a range of control mechanisms might exist for a particular steroid to modulate the expression of different genes, and in different tissues this " mix " of control could be variable. 
Acknowledgements. - I wish to thank P. Davies, B. Perry and A. Toong for critical reading of the manuscript. I also want to express my gratitude to Nelly Dorr for typewriting the manuscript.

\section{Résumé. Contrôle de l'expression génétique par les hormones stéroïdes.}

Le mécanisme d'action des hormones stéroïdes implique leur interaction avec des sites de liaison spécifiques du tissu cible, de laquelle résulte une modulation précise de l'expression génétique. Dans les tissus cibles, il existe pour les hormones stéroïdes des récepteurs à haute affinité, ainsi que des sites de liaison secondaire. Dans plusieurs cas, il a été démontré que les complexes hormone-récepteur sont capables de réguler directement la transcription, ceci en se liant à des régions de l'ADN situées à proximité des gènes contrôlés. Cependant, d'autres données expérimentales suggèrent que les hormones stéroïdes pourraient aussi moduler la transcription en modifiant la structure de la chromatine. Dans ce cas, leur action se traduirait par des modifications posttraductionnelles de protéines histones et non-histones, ainsi que par des variations des proportions relatives des isoformes d'histones. Hormis la transcription, il est aussi désormais concevable que les hormones stéroïdes modulent effectivement l'expression génétique en régulant certaines étapes de la maturation des ARN. Le rôle respectif de récepteurs de haute affinité ou de sites secondaires dans un contrôle direct de ces phénomènes reste cependant inconnu. Ces quelques remarques suggèrent l'existence de plusieurs niveaux d'action permettant d'assurer un contrôle précis de l'expression génétique par les hormones stérö̈des.

\section{Références}

ABELSON J., 1979. RNA processing and the intervening sequence problem. Ann. Rev. Biochem., 48, $1035-1069$.

ADAMS R. L. P., Mc KAY E. L., CRAIG L. M., BURDON R. H., 1979. Mouse DNA methylase : methylation of native DNA. Biochim. Biophys. Acta, 561, 345-357.

ALEXANDROVA E. A., MAREKOV L. N., BELTCHEV B. G., 1984. Involvement of protein HMG1 in DNA replication. FEBS Lett., 178, 153-156.

ALLAN J., HARTMAN P. G., CRANE-ROBINSON C., AVILES F. X., 1980. The structure of histone $\mathrm{H} 1$ and its location in chromatin. Nature, 288, 675-679.

ALLFREY V. G., 1982. Post synthetic modifications, 123-148. In JOHNS E. W., The HMG chromosomal proteins. Acad. Press, New York.

ALLIS C. D., ZIEGLER Y. S., GOROVSKY M. A., OLMSTED J. B., 1982. A conserved histone variant enriched in nucleoli of mammalian cells. Cell, 31, 131-136.

AMARA S. G., JONAS V., ROSENFELD M. G., ONG E. S., EVANS R. M., 1982. Alternative RNA processing in calcitonin gene expression generates mRNAs encoding different polypeptide products. Nature, 298, 240-245.

AURICCHIO F., MIGLIACCIO A., 1980. In vitro inactivation of oestrogen receptor by nuclei. FEBS Lett., 117, 224-226.

AURICCHIO F., MIGLIACCIO A., ROTONDI A., 1981a. Inactivation of oestrogen in vitro by nuclear dephosphorylation. Biochem. J., 194, 569-574.

AURICCHIO F., MIGLIACCIO A., CASTORIA G., LASTORIA S., SCHIAVONE E., 1981b. ATPdependent enzyme activating hormone binding of oestradiol receptor. Biochem. biophys. Res. Commun., 101, 1171-1178. 
AURICCHIO F., MIGLIACCIO A., CASTORIA G., ROTONDI A., LASTORIA S., 1984. Direct evidence of in vitro phosphorylation-dephosphorylation of the estradiol-17 $\beta$ receptor, role of $\mathrm{Ca}^{2+}$-calmodulin in the activation of hormone binding sites. J. Steroid Biochem., 20, 31-35.

BAKKEN A., MORGAN G., SOLLNER-WEBB B., ROAN J., BUSBY S., REEDER R. H., 1982. Mapping of transcription initiation and termination signals on Xenopus Laevis ribosomal DNA. Proc. nat. Acad. Sci. USA, 79, 56-60.

BARLOW J. W., KRAFT N., STOCKIGT J. R., FUNDER J. W., 1979. Predominant high affinity binding of $\left[{ }^{3} \mathrm{H}\right]$ dexamethasone in bovine tissues is not to classical glucorticoid receptors. Endocrinology, 105, 827-834.

BARRACK E. R., COFFEY D. S., 1980. The specific binding of estrogens and androgens to the nuclear matrix of sex hormone responsive tissues. J. biol. Chem., 255, 7265-7275.

BÉCHET D. M., PERRY B. N., LOVELL R., TOONG A., 1983. Liver nuclear steroid receptors, affinities and anabolic agent competition. J. Steroid Biochem., 19, $28 \mathrm{~S}$.

BÉCHET D. M., PERRY B. N., 1986. A novel class of inactive steroid binding sites in female rat liver nuclei. J. Endocrin., 110, 27-36.

BÉCHET D. M., PERRY B. N., TOONG A., LOVELL R. D., 1986a. Oestrogen specific binding sites in bovine muscle nuclei. J. Steroid Biochem., 24, 1127-1134.

BÉCHET D. M., PERRY B., TOONG A., 1986b. Compartmentation of oestradiol receptors in rat liver nuclei. 2. Receptor characterization and subnuclear distribution after oestradiol injection. (Submitted for publication).

BEHE M., FELSENFELD G., 1981. Effects of methylation on a synthetic polynucleotide : The B-Z transition in poly (dG-m5dC). Poly (dG-m $\left.\mathrm{m}^{5} \mathrm{dC}\right)$. Proc. nat. Acad. Sci. USA, 78, 1619-1623.

BELLARD M., KUO M. T., DRETZEN G., CHAMBON P., 1980. Differential nuclease sensitivity of the ovalbumin and $\beta$-globin chromatin regions in erythrocytes and oviduct cells of laying hen. Nucleic Acids Res., 8, 2737-2750.

BENEZRA R., BLANKSTEIN L. A., STOLLAR B. D., LEVY S. B., 1981. Immunological and organization hererogeneity of histone $\mathrm{H} 2 \mathrm{~A}$ variants within chromatin of cells at different stages of Friend leukemia. J. biol. Chem., 256, 6837-6841.

BENYAJATI C., WORCEL A., 1976. Isolation, characterization and structure of the folded interphase genome of Drosophila melanogaster. Cell, 9, 393-407.

BERGET S. M., 1984. Are U4 small nuclear ribomucleoproteins involved in polyadenylation ? Nature, 309, 179-182.

BIRD A. P., TAGGART M. H., GEHRING C. A., 1981. Methylated and unmethylated ribosomal RNA genes in the mouse. J. mol. Biol., 152, 1-17.

BIRNBAUMER M., WEIGEL N. L., MINGHETTI P. P., GRODY W. W., SHRADER W. T., O'MALLEY B. W., 1981. The structure and function of the progesterone receptor, 29-47. In LEWIS G. P., GINSBURG M., Mechanisms of steroid action. MacMillan Press Ltd, London.

BIRNSTIEL M. L., BUSSLINGER M., STRUB K., 1985. Transcription termination and $3^{\prime}$ processing : the end is in site ! Cell, 41, 349-359.

BODINE P. V., SCHMIDT T. J., LITWACK G., 1984. Evidence that $\mathrm{pH}$ induced activation of the rat hepatic glucocorticoid-receptor complex is irreversible. J. Steroid Biochem., 20, 683-689.

BOYD-LEINEN P., GOSSE B., RASMUSSEN K., MARTIN-DANI G., SPELSBERG T. C., 1984. Regulation of nuclear binding to the avian oviduct progesterone receptor. J. biol. Chem., 259, 2411-2421.

BREATHNACH R., CHAMBON P., 1981. Organization and expression of eucaryotic split genes coding for proteins. Ann. Rev. Biochem., 50. 349-383.

BRODY E., ABELSON J., 1985. The " spliceosome " : yeast pre-messenger RNA associates with a $40 \mathrm{~S}$ complex in a splicing-dependent reaction. Science, 228, 963-967.

BRUNEL C., SRI WIDADA J., LELAY M.-N., JEANTEUR P., LIANTARD J. -P., 1981. Purification and characterization of a simple ribonucleoprotein particle containing small nucleoplasmic RNAs (snRNP) as a subset of RNP containing cells. Nucleic Acids Res., 9, 815-830.

BURDON R. H., ADAMS R. L. P., 1969. The in vivo methylation of DNA in mouse fibroblasts. Biochim. Biophys. Acta, 174, 322-329.

BUSCH H., REDDY R., ROTHBLUM L., CHOI Y. C., 1982. SnRNAS, SnRNPs, and RNA processing. Ann. Rev. Biochem., 51, 617-654. 
BUSSLINGER M., HURST J., FLAVELL R. A., 1983. DNA methylation and the regulation of globin gene expression. Cell, 34, 197-206.

CAKE M. H., GOIDL J. A., PARCHMAN L. G., LITWACK G., 1976. Involvement of a low molecular weight component(s) in the mechanism of action of the glucocorticoid receptor. Biochem. biophys. Res. Commun., 71, 45-52.

CAKE M. H., DISORBO D. M., LITWACK G., 1978. Effect of pyridoxal phosphate on the DNA binding site of activated hepatic glucorticoid receptor. J. biol. Chem., 253, 4886-4891.

CARON F., THOMAS J. O., 1981. Exchange of histone $\mathrm{H} 1$ between segments of chromatin. J. mol. biol., 146, 513-537.

CATO A. C. B., GeIsSE S., WENZ M., WESTPhAL H. M., BeATo M., 1984. The nucleotide sequences recognized by the glucocortocoid receptor in the rabbit uteroglobin gene region are located far upstream from the initiation of transcription. EMBO J., 3, 2771-2778.

CHOI Y. D., DREYFUSS G., 1984. Isolation of the heterogeneous nuclear RNA-ribonucleoprotein complex (hnRNP) : a unique supramolecular assembly. Proc. nat. Acad. Sci. USA., 81, 74717475.

CHONG M. T., LIPPMAN M. E., 1982. Effects of RNA and ribonuclease on the binding of estrogen and glucocorticoid receptors from MCF-7 cells to DNA-cellulose. J. biol. Chem., 257, 29963002.

CIEJEK E. M., TSAI M.-J., O'MALLEY B. W., 1983. Actively transcribed genes are associated with the nuclear matrix. Nature, 306, 607-609.

CLARK J. H., HARDIN J. W., UPCHURCH S., ERIKSSON H., 1978. Heterogeneity of estrogen binding sites in the cytosol of the rat uterus. J. biol. Chem., 253, 7630-7634.

CLARK J. H., MARKAVERICH B. M., 1981. Relationships between type I and II estradiol binding sites and estrogen induced responses. J. Steroid Biochem., 15, 49-54.

CLARK J. H., MARKAVERICH B. M., 1982. Heterogeneity of estrogen binding sites and the nuclear matrix, 259-288. In MAUL G., The nuclear envelope and the nuclear matrix. Liss, New York.

CLARKSON S. G., 1983. Transfert RNA genes, 239-261. In MACLEAN N., GREGORY S. P., FLAVELL R. A., Eukaryotic genes, their structure, activity and regulation. Butterworths, London.

CLAWSON G. A., FELDHERR C. M., SMUCKLER E. A., 1985. Nucleocytoplasmic RNA transport. Mol. cell. Biochem., 67, 87-100.

COCHRANE A. W., DEELEY R. G., 1984. Estrogen-dependent modification of ribosomal proteins. J. biol. Chem., 259, 15408-15413.

COMPTON J. G., SCHRADER W. T., O'MALLEY B. W., 1983. DNA sequence preference of the progesterone receptor. Proc. nat. Acad. Sci. USA, 80, 16-20.

COX R. F., 1977. Estrogen withdrawal in chick oviduct. Selective loss of high abundance classes of polyadenylated messenger RNA. Biochemistry, 16, 3433-3443.

DAHLBERG E., SNOCKOWSKI M., GUSTAFSSON J.-A., 1981. Regulation of the androgen and glucocorticoid receptors in rat and mouse sketetal muscle cytosol. Endocrinology, 108, 14311440.

DEAN D. C., KNOLL B. J., RISER M. E., O'MALLEY B. W., 1983. A $5^{\prime}$-flanking sequence essential for progesterone regulation of an ovalbumin fusion gene. Nature, 305, 551-554.

DICKSON R. B., ATEN R. F., EISENFELD A. J., 1978. An unusual sex steroid-binding protein in mature male rat liver cytosol. Endocrinology, 103, 1636-1646.

DI MARIA P. R., KALTWASSER G., GOLDENBERG C. J., 1985. Partial purification and properties of a pre-mRNA splicing activity. J. biol. Chem., 260, 1096-1102.

DIMITRIADIS G. J., TATA J. R., 1980. Subnuclear fractionation by mild micrococcal-nuclease treatment of nuclei of different transcriptionnal activities causes a partition of expressed and non-expressed genes. Biochem. J., 187, 467-477.

DISORBO D. M., PHELPS D. S., OHL V. S., LITWACK G., 1980. Pyridoxine deficiency influences the behavior of the glucocorticoid-receptor complex. J. biol. Chem., 255, 3866-3870.

DO Y. S., LOOSE D. L., FELDMAN D., 1979. Heterogeneity of glucocorticoid binders : a unique and a classical dexamethasone-binding site in bovine tissues. Endocrinolgy, 105, 1055-1063.

DOERFLER W., 1983. DNA methylation and gene activity. Ann. Rev. Biochem., 52, 93-124.

DOUGHERTY J. J., PURI R. K., TOFT D.O., 1982. Phosphorylation in vivo of chicken oviduct progesterone receptor. J. biol. Chem., 257, 14226-14230. 
EAGON P. K., FISHER S. E., FORREST IMHOFF A., PORTER L. E., STEWART R. R., VAN THIEL D. H., LESTER R., 1980 . Estrogen-binding proteins of male rat liver: influences of hormonal changes. Arch. Biochem. Biophys. 201, 486-499.

ECONOMIDIS I. V., ROUSSEAU G. G., 1985. Association of the glucocorticoid hormone receptor with ribonucleic acid. FEBS Lett., 181, 47-52.

EISENFELD A. J., ATEN R. F., DICKSON R. B., 1980. Estrogen receptor in the mammalian liver, 6996. In Mc LACHLAN J. A., Estrogens in the environment, Elsevier North Holland.

EMERSON B. M., FELSENFELD G., 1984. Specific factors conferring nuclease hypersensitivity at the $5^{\prime}$ of the chicken adult $\beta$-globin gene. Proc. nat. Acad. Sci. USA, 81, 95-99.

ERIKSSON H., UPCHURCH S., HARDIN J. W., PECK E. J., CLARK J. H., 1978. Heterogeneity of estrogen receptors in the cytosol and nuclear fractions of the rat uterus. Biochem. biophys. Res. Commun., 81, 1-7.

FELDMAN M., KALLOS J., HOLLANDER V. P., 1981. RNA inhibits estrogen receptor binding to DNA. J. biol. Chem., 256, 1145-1148.

FRANKE W. W., SCHEER U., 1978. Morphology of transcriptional units at different states of activity. Phil. Trans. roy. Soc. Lond. B., 283, 333-342.

FRENDEWEY D., KELLER W., 1985. Stepwise assembly of a pre-mRNA splicing complex requires U-snRNPs and specific intron sequences. Cell, 42, 355-367.

FRITTON H. P., IGO-KEMENES T., NOWOCK J., STRECH-JURK U., THEISEN M., SIPPEL A. E., 1984. Alternative sets of DNase I-hypersensitive sites characterize the various functional states of the chicken lysozyme gene. Nature, 311, 163-165.

GALLINARO H., JACOB M., 1981. The status of small nuclear RNA in the ribonucleoprotein fibrils containing heterogeneous nuclear RNA. Biochim. Biophys. Acta, 652, 109-120.

GALLINARO H., LAZAR E., JACOB M., KROL A., BRANLANT C., 1981. Small RNAs in HnRNP fibrils and their possible function in splicing. Mol. Biol. Rep., 7, 31-39.

GALLINARO H., PUVION E., KISTER L., JACOB M., 1983. Nuclear matrix and hnRNP share a common structural constituent associated with premessenger RNA. EMBO J., 2, 953-960.

GAREL A., AXEL R., 1976. Selective digestion of transcriptionally active ovalbumin genes from oviduct. Proc. nat. Acad. Sci. USA, 73, 3966-3970.

GAZIT B., PANET A., CEDAR H., 1980. Reconstitution of a deoxyribonuclease I-sensitive structure on active genes. Proc. nat. Acad. Sci. USA, 77, 1787-1790.

GIL A., PROUDFOOT N. J., 1984. A sequence downstream of AAUAAA is required for rabbit $\beta$ globin mRNA $3^{\prime}$-end formation. Nature, 312, 473-474.

GIORGI E. P., 1976. Studies on androgen transport into canine prostate in vitro. J. Endocr., 68, 109-119.

GIORGI E. P., 1980. The transport of steroid hormones into animals cells. Int. Rev. Cytol., 65, 49-115.

GJERSET R. A., MARTIN D. W., 1982. Presence of DNA demethylating activity in the nucleus of murine erythroleukemic cells. J. biol. Chem., 257, 8581-8583.

GLOVER D. M., 1983. Genes for ribosomal RNA, 207-224. In MACLEAN N., GREGORY S. P., FLAVELL R. A., Eukaryotic genes, their structure, activity and regulation. Butterworths, London.

GOODWIN G. H., MATHEW C. G. P., 1982. Role in gene structure and function, 193-221. In JOHNS E. W., The HMG chromosomal proteins. Acad. Press, New York.

GOTTESFELD J. M., 1977. Methods for fractionation of chromatin into transcriptionally active and inactive segments. Methods Cell Biol., 16, 421-436.

GOVINDAN M. V., SPIESS E., MAJORS J., 1982. Purified glucocorticoid receptor-hormone complex from rat liver cytosol binds specifically to cloned mouse mammary tumor virus long terminal repeats in vitro. Proc. nat. Acad. Sci. USA, 79, 5157-5161.

GRAAF G., VON HOLT C., 1973. Enzymatic histone modification during the induction of tyrosine aminotransferase with insulin and hydrocortisone. Biochim. Biophys. Acta, 299, 480-484.

GRABOWSKI P. J., SEILER S. R., SHARP P. A., 1985. A multicomponent complex is involved in the splicing of messenger RNA precursors. Cell, 42, 345-353.

GREEN S., WALTER P., KUMAR V., KRUST A., BORNERT J. M., ARGOS P., CHAMBON P., 1986. Human oestrogen receptor CDNA : sequence, expression and homology to v-erb-A. Nature, 320, 134-139. 
GREeR C. L., PEebles C. L., GEgenheimeR P., ABELSON J., 1983. Mechanism of action of a yeast RNA ligase in tRNA splicing. Cell, 32, 537-546.

GRIPPO J. F., TIENRUNGROJ W., DAHMER M. K., HOUSLEY P. R., PRATT W. B., 1983. Evidence that the endogenous heat-stable glucocorticoid receptor-activating factor is thioredoxin. J. biol. Chem., 258, 13658-13664.

GRIPPO J. F., HOLMGREN A., PRATT W. B., 1985. Proof that the endogenous heat-stable glucocorticoid recepetor-activating factor is thioredoxin. J. biol. Chem., 260, 93-97.

GRODY W. W., COMPTON J. G., SCHRADER W. T., O'MALLEY B. W., 1980. Inactivation of chick oviduct progesterone receptors. J. Steroid Biochem., 12, 115-119.

GRONER B., KENNEDY N., SKROCH P., HYNES N. E., PONTA H., 1984. DNA sequences involved in the regulation of gene expression by glucocorticoid hormones. Biochim. Biophys. Acta, $781,1-6$.

GROSSCHEDL R., BIRNSTIEL M. L., 1980. Indentification of regulatory sequences in the prelude sequences of an H2A histone gene by the study of specific deletion mutants in vivo. Proc. nat. Acad. Sci. USA, 77, 1432-1436.

GROUDINE M., WEINTRAUB H., 1981. Activation of globin genes during chicken development. Cell, 24. 393-401.

GRUMMT I., 1982. Nucleotide sequence requirements for specific initiation of transcription by RNA polymerase 1. Proc. nat. Acad. Sci USA, 79, 6908-6911.

HARAUZ G., OTTENSMEYER F. P., 1984. Nucleosome reconstruction via phosphorus mapping. Science, 266, 936-940.

HERMAN R., WEYMOUTH L., PENMAN S., 1978. Heterogenous nuclear RNA-protein fibers in chromatin-depleted nuclei. J. Cell Biol., 78, 663-674.

HOLLENBERG S. M., WEINBERGER B., ONG E. S., CERELLI G., ORO A., LEBO R., THOMPSON E. B., ROSENFELD M. G., EVANS R. M., 1985. Primary structure and expression of a functional human glucocorticoid receptor cDNA. Nature, 318, 635-641.

HORWITZ K. B., MC GUIRE W. L., 1980. Nuclear estrogen receptors : effect of inhibitors on processing and steady state levels. J. biol. Chem., 255, 9699-9705.

HOUSLEY P. R., PRATT W. B., 1983. Direct demonstration of glucocorticoid receptor phosphorylation by intact L-cells. J. biol. Chem., 258, 4630-4635.

HOUSLEY P. R., GRIPPO J. F., DAHMER M. K., PRATT W. B., 1984. Inactivation, activation and stabilization of glucocorticoid receptors, 347-376 Vol. XI. In LITWACK G., Biochemical actions of hormones, Acad. Press, Inc.

HUEZ G., BRUCK C., CLEUTER Y., 1981. Translational stability of native and deadenylated rabbit globin mRNA injected into HeLa cells Proc. nat. Acad. Sci. USA, 78, 908-911.

IGO-KeMENES T., HORZ W., ZACHAU H. G., 1982. Chromatin. Ann. Rev. Biochem., 51, 89-121.

ISACKSON P. J., FISHBACK J. L., BIDNEY D. L., REECK G. R., 1979. Preferential affinity of high molecular weight high mobility group non-histone chromatin proteins for single-stranded DNA. J. biol. Chem., 254, 5569-5572.

JACKSON D. A., Mc CREADY S. J., COOK P. R., 1984. Replication and transcription depend on attachment of DNA to the nuclear cage. J. Cell Sci. Suppl., 1, 59-79.

JAVAHERIAN K., LIU L. F., WANG J. C., 1978. Nonhistone proteins HMG1 and HMG2 change the DNA helical structure. Science, 190, 1345-1346.

JELINEK W., DARNELL J. E., 1972. Doucle-stranded regions in heterogeneous nuclear RNA from HeLa cells. Proc. nat. Acad. Sci. USA, 69, 2537-2541.

JELINEK W., MOLLOY G., FERNANDEZ-MUNOZ R., SALDITT M., DARNELL J. E., 1974. Secondary structure in heterogeneous nuclear RNA : involvement of regions from repeated DNA sites. J. mol. Biol., 82, 361-370.

JENSEN E. V., SUZUKI T., KAWASHINA T., STUMPF W. E., JUNGBLUT P. W., DESOMBRE E. R., 1968. A two-step mechanism for the interaction of estradiol with rat uterus. Proc. nat. Acad. Sci. USA, 59, 632-638.

JOST J. P., SELDRAN M., 1984. Association of transcriptionally active vitellogenin II gene with the nuclear matrix of chicken liver. EMBO J., 3, 2005-2008.

JOST J.-P., SELDRAN M., GEISER M., 1984. Preferential binding of estrogen-receptor complex to a region containing the estrogen-dependent hypomethylation site preceding the chicken vitellogenin II gene. Proc. nat. Acad. Sci. USA, 81, 429-433. 
JOVE R., MANLEY J. L., 1982. Transcription initiation by RNA polymerase II is inhibited by Sadenosylhomocysteine. Proc. nat. Acad. Sci. USA, 79, 5842-584.

KALLOS J., FASY T. M., HOLLANDER V. P., 1981. Assessment of estrogen receptor-histone interactions. Proc. nat. Acad. Sci. USA, 78, 2874-2878.

KARIN M., HASLINGER A., HOLTGREVE H., RICHARDS R. I., KRAUTER P., WESTPHAL H. M., BEATO M., 1984. Characterization of DNA sequences through which cadmium and glucocorticoid hormones induce human metallothione in-llA gene. Nature, 308, 513-519.

KASID A., STROBL K., GREENE G. L., LIPPMAN M. E., 1984. A novel nuclear form of estradiol receptor in MCF-7. human breast cancer cells. Science, 225, 1162-1165.

KAYE J. S., BELLARD M., DRETZEN G., BELLARD F., CHAMBON P., 1984. A close association between sites of DNase I hypersensitivity and sites of enhanced cleavage by micrococcal nuclease in the $5^{\prime}$-flanking region of the actively transcribed ovalbumin gene. EMBO J., 3 , 1137-1144.

KING W. J., GREENE G. L., 1984. Monoclonal antibodies localize oestrogen receptor in the nuclei of target cells. Nature, 307, 745-747.

KISH V. M., PEDERSON T., 1977. Heterogeneous nuclear RNA secondary structure : oligo(U) sequences base-paired with poly(A) and their possible role as binding sites for heterogeneous nuclear RNA-specific proteins. Proc. nat. Acad. Sci. USA, 74, 1426-1430.

KON L., SPELSBERG T. C., 1982. Nuclear binding of estrogen-receptor complex : receptor-specific nuclear acceptor sites. Endocrinology, 111, 1925-1935.

KONARSKA M. M., PADGETT R. A., SHARP P. A., 1984. Recognition of cap structure in splicing in vitro of mRNA precursors. Cell, 38, 731-736.

KONARSKA M. M., GRABOWSKI P. J., PADGETT R. A., SHARP P. A., 1985. Characterization of the branch site in lariat RNAs produced by splicing of mRNA precursors. Nature, 313, 552557.

KUDOLO G. B., ELDER M. G., MYATT L., 1984a. A novel oestrogen-binding species in rat granulosa cells. J. Endocr., 102, 83-91.

KUDOLO G. B., ELDER M. G., MYATT L., 1984b. Further characterization of the second oestrogenbinding species of the rat granulosa cell. J. Endocr., 102, 93-102.

LASKEY R. A., EARNSHAW W. C., 1980. Nucleosome assembly. Nature, 286, 763-767.

LASTERS I., MUYLDERMANS S., WYNS L., HAMERS R., 1981. Differences in rearrangements of $\mathrm{H} 1$ and $\mathrm{H5}$ in chicken erythrocyte chromatin. Biochemistry, 20, 1104-1110.

LAWSON G. M., TSAI M. J., O'MALLEY B. W., 1980. Deoxyribonuclease I sensitivity of the nontranscribed sequences flanking the $5^{\prime}$ and $3^{\prime}$ ends of the ovomucoid gene and the ovalbumin and its related $X$ and $Y$ genes in hen oviduct nuclei. Biochemistry, 19, 4403-4411.

LEACH K. L., GRIPPO J. F., HOUSLEY P. R., DAHMER M. K., SALIVE M. E., PRATT W. B., 1982. Characteristics of an endogenous glucocorticoid receptor stabilizing factor. J. biol. Chem., 257, 381-388.

LEE F., MULLIGAN R., BERG P., RINGOLD G., 1981. Glucocorticoids regulate expression of dehydrofolate reductase cDNA in mouse mammary tumor virus chimaeric plasmids. Nature, 294, 228-232.

LEPAULT J., BRAM S., ESCAIG J., WRAY W., 1980. Chromatin freeze fracture electron microscopy : a comparative study of core particles, chromatin, metaphase chromosomes, and nuclei. Nucleic Acids Res., 8, 265-278.

LERNER M. R., BOYLE J. A., MOUNT S. M., WOLIN S. L., STEITZ J. A., 1980. Are snRNPS involved in splicing? Nature, 283, 220-224.

LESER G. P., ESCARA-WILKE J., MARTIN T. E., 1984. Monoclonal antibodies to heterogeneous nuclear RNA-protein complexes. J. biol. Chem., 259, 1827-1833.

LEVY B., DIXON G. H., 1978. Partial purification of transcriptionally active nucleosomes from trout testis cells. Nucleic Acids Res., 5, 4155-4163.

LEVY-WILSON B., WATSON D. C., DIXON G. H., 1979a. Multiacetylated forms of H4 are found in a putative transcriptionally competent chromatin fraction from trout testis. Nucleic Acids Res., 6. 259-274.

LEVY-WILSON B., CONNOR W., DIXON G. H., 1979b. A subset of tront testis nucleosomes enriched in transcribed DNA sequences contains high mobility group proteins as major structural components. J. biol. Chem., 254, 609-620. 
LIANG T., CASTANEDA E., LIAO S., 1977. Androgen and initiation of protein synthesis in the prostate. J. biol. Chem., 252, 5692-5700.

LIANG T., LIAO S., 1974. Association of the uterine $17 \beta$-estradiol- receptor complex with ribonucleoprotein in vitro and in vivo. J. biol. Chem., 249, 4671-4678.

LIAO S., LIANG T., TYMOCZKO J. L., 1973. Ribonucleoprotein binding of steroid-receptor complexes. Nature New Biol., 241, 211-213.

LIAO S., SMYTHE S., TYMOCZKO J. L., ROSSINI G. P., CHEN C., HIIPAKKA R.A., 1980. RNAdependent release of androgen- and other steroid- receptor complexes from DNA. J. biol. Chem., 255, 5545-5551.

LIBBY P. R., 1972. Histone acetylation and hormone action. Early effect of estradiol-17 $\beta$ - on histone acetylation in rat uterus. Biochem. J., 130, 663-669.

LIN S. Y., OHNO S., 1983. Interactions of nuclear estrogen receptor with DNA and RNA. Biochim. Biophys. Acta, 740, 264-270.

LOUTERS L., CHALKLEY R., 1985. Exchange of histones $\mathrm{H} 1, \mathrm{H} 2 \mathrm{~A}$ and $\mathrm{H} 2 \mathrm{~B}$ in vivo. Biochemistry, 24, 3080-3085.

MAC DONALD R. G., LEAVITT W. W., 1982. Reduced sulfhydryl groups are required for activation of uterine progesterone receptor. J. biol. Chem., 257, 311-315.

MALIK N., SMULSON M., BUSIN M., 1984. Enrichment of acetylated histones in polynucleosomes containing high mobility group protein 17 revealed by immunoaffinity chromatography. $J$. biol. Chem., 259, 699-702.

MARKAVERICH B. M., CLARK J. H., 1979. Two binding sites for estradiol in rat uterine nuclei : relationship to uterotropic response. Endocrinology, 105, 1458-1462.

MARKAVERICH B. M., UPCHURCH S., CLARK J. H., 1981. Progesterone and dexamethasone antagonism of uterine growth : a role for a second nuclear binding site for estradiol in estrogen action. J. Steroid Biochem., 14, 125-132.

MATARADZE G. D., KONDRATYEV Y. Y., GONTAR E. V., SMIRNOV A. N., ROZEN V. B., 1981. Basic principles of translocation of different forms of liver estrogen receptors from the cytoplasm to the nucleus. Bull. exp. Biol. Med. (USSR), 91, 568-571.

MATHIS D., OUDET P., CHAMBON P., 1980. Structure of transcribing chromatin. Prog. nucleic Acid Res. mol. Biol., 24, 1-55.

Mc BLAIN W. A., TOFT D. O., 1983. Interaction of chick oviduct progesterone receptor with the 2', 3'-dialdehyde derivative of adenosine $5^{\prime}$-tryphosphate. Biochemistry, 22, 2262-2270.

Mc GHEE J. D., FELSENFELD G., 1980. Nucleosome structure. Ann. Rev. Biochem., 49, 1115-1156.

Mc KNIGHT G. S., PALMITER R. D., 1979. Transcriptional regulation of the ovalbumin and conalbumin genes by steroid hormones in chick oviduct. $J$. biol. Chem., 254, 9050-9058.

MICHEL G., BAULIEU E. E., 1980. Androgen receptor in rat skeletal muscle : characterization and physiological variations. Endocrinology, 107, 2088-2098.

MIESFELD R., OKRET S., WIKSTROM A.-C., WRANGE O., GUSTAFSSON J.-A., YAMAMOTO K. R., 1984. Characterization of a steroid hormone receptor gene and mRNA in wild-type and mutant cells. Nature, 312, 779-781.

MILGROM E., ATGER M., BAULIEU E. E., 1973. Acidophilic activation of steroid hormone receptor. Biochemistry, 12, 5198-5205.

MILLER J. R., 1983. 5S Risosomal RNA genes, 225-237. In MACLEAN N., GREGORY S. P., FLAVELL R. A., Eukaryotic genes, their structure, activity and regulation, Butterworths, London.

MILLER T. E., HUANG C.-Y., POGO A. O., 1978a. Rat liver nuclear skeleton and ribonucleoprotein complexes containing HnRNA. $J$. Cell Biol., 76, 675-691.

MILLER T. E., HUANG C.-Y., POGO A. O., 1978b. Rat liver nuclear skeleton and small molecular weight RNA species. J. Cell Biol., 76, 692-704.

MIROSHNICHENKO M. L., SMIRNOVA O. V., SMIRNOV A. N., ROZEN V. B., 1983. The unusual estrogen-binding protein (UEBP) of male rat liver: structural determinants of ligands. $J$. Steroid Biochem., 18, 403-409.

MOORE C. L., SHARP P. A., 1984. Site-specific polyadenylation in a cell-reaction. Cell, 36, 581-591.

MOORE D. D., MARKS A. R., BUCKLEY D. I., KAPLER G., PAYVAR F., GOODMAN H. M., 1985. The first intron of the human growth hormone gene contains a binding site for glucocorticoid receptor. Proc. nat. Acad. Sci. USA, 82, 699-702. 
MÜLLER R. E., JOHNSTON T. C., WOTIZ H. H., 1979. Binding of estradiol to purified uterine plasma membranes. J. biol. Chem., 254, 7895-7900.

MULVIHILL E. R., LE PENNEC J. P., CHAMBON P., 1982. Chicken oviduct progesterone receptor ; location of specific regions of high-affinity binding in cloned DNA fragments of hormoneresponsive genes. Cell, 24, 621-632.

MURRAY A. B., DAVIES H. G., 1979. Three-dimensional reconstitution of the chromatin bodies in the nuclei of mature erythrocytes from the newt Triturus cristatus : the number of nuclear envelope-attachment sites. J. Cell Sci, 35, 59-66.

NAVEH-MANY T., CEDAR H., 1981. Active gene sequences are undermethylated. Proc. nat. Acad. Sci. USA, 78, 4246-4250.

NEVINS J. R., 1983. The pathway of eukaryotic mRNA formation. Ann. Rev. Biochem., 52, 441-466.

NIELSEN C. J., SANDO J. J., VOGEL W. M., PRATT W. B., 1977. Glucorticoid receptor inactivation under cell-free conditions. J. biol. Chem., 252, 7568-7578.

NISHIGORI H., TOFT D. O., 1980 . Inhibition of progesterone receptor activation by sodium molybdate. Biochemistry, 19, 77-83.

NORDHEIM A., PARDUE M. L., LAFER E. M., MOLleR A., STOLLAR B. D., RICH A., 1981. Antibodies to left-handed Z-DNA bind to interband regions of Drosophila polytene chromosomes. Nature, 294, 417-422.

NORDHEIM A., RICH A., 1983. Negatively supercoiled SV40 DNA contains Z-DNA segments within transcriptional enhancer sequences. Nature, 303, 674-679.

PAGE M. J., PARKER M. G., 1982. Effect of androgen on the transcription of rat prostatic binding protein genes. Mol. cell. Endocrinol., 27, 343-355.

PALMITER R. D., CAREY N. H., 1974. Rapid inactivation of ovalbumin messenger ribonucleic after acute withdrawal of estrogen. Proc. nat. Acad. Sci. USA, 71, 2357-2361.

PARDOLL D. M., VOGELSTEIN B., COFFEY D. S., 1980. A fixed site of DNA replication in eukaryotic cells. Cell, 19, 527-536.

PASQUALINI J. R., COSQUER-CLAVREUL C., VIDALI G., ALLFREY V. G., 1981. Effects of estradiol on the acetylation of histones in the fetal uterus of the Guinea pig. Biol. Reprod., 25, 1035-1039.

PAYS E., FLAMAND J., 1976. Location of endogenous RNA polymerase B in a sub-fraction of rat liver chromatin. FEBS Letters, 61, 166-170.

PAYVAR F., WRANGE O., CARLSTEDT-DUKE J., OKRET S., GUSTAFSSON J.-A., YAMAMOTO K. R., 1981. Purified glucocorticoid receptors bind selectively in vitro to a cloned DNA fragment whose transcription is regulated by glucocorticoids in vivo. Proc. nat. Acad. Sci. USA, 78, 6628-6632.

PEEBLES C. L., GEGENHEIMER P., ABELSON J., 1983. Precise excision of intervening sequences from precursor tRNA by a membrane-associated yeast endonuclease. Cell, 32, 525-536.

PERRY B. N., LOPEZ A., 1978. The binding of ${ }^{3} \mathrm{H}$-labelled oestradiol and progesterons-receptor complexes to hypothalamic chromatin of male and female sheep. Biochem. J., 176, 873-883.

PFAHL M., 1982. Specific binding of the glucocorticoid-receptor complex to the mouse mammary tumor proviral promoter region. Cell, 31, 475-482.

PIENTA K. J., COFFEY D. S., 1984. A nuclear analysis of the role of the nuclear matrix and DNA loops in the organization of the nucleus and chromosome. J. Cell Sci. Suppl., 1, 123-135.

PIETRAS R. J., SZEGO C. M., 1977. Specific binding sites for oestrogen at the outer membranes of isolated endometrial cells, Nature (London), 265, 69-72.

PROUDFOOT N. J., BROWNLEE G. G., 1976. 3' non-coding region sequences in eukaryotic messenger RNA. Nature, 263, 211-214.

PUVION E., MOYNE G., 1981. In situ localization of RNA structures, 59-115 vol. VIII. In BUSCH H., The cell nucleus, Acad. Press, New York.

REDEUILH G., SECCO C., BAULIEU E. E., RICHARD-FOY H., 1981. Calf estradiol receptor : effects of molybdate on salt-induced transformation. J. biol. Chem., 256, 11496-11502.

REED R., MANIATIS T., 1985. Intron sequences involved in lariat formation during pre-RNA splicing. Cell, 41, 95-105.

RENKAWITZ R., BEUG H., GRAF T., MATTHIAS P., GREZ M., SCHUTZ G., 1982. Expression of a chicken lysozyme recombinant gene is regulated by progesterone and dexamethasone after microinjection into oviduct cells. Cell, 31, 168-176. 
ROBINSON S. I., SMALL D., IDZERDA R., Mc KNIGHT G. S., VOGELSTEIN B., 1983. The association of transcriptionally active genes with the nuclear matrix of the chicken oviduct. Nucleic Acids Res., 11, 5113-5130.

ROGERS J., WALL R., 1980. A mechanism for RNA splicing. Proc. nat. Acad. Sci. USA, 77, 18771879.

ROSE K. M., JACOB S. T., KUMAR A., 1979. Poly(A) polymerase and poly(A)-specific mRNA binding protein are antigenically related. Nature, 279, 260-262.

ROSS P., RUH T., 1984. Binding of the estradiol-receptor complex to reconstituted nucleoacidic protein from calf uterus. Biochim. Biophys. Acta, 782, 18-25.

ROUSSEAU G. G., HIGGINS S. J., BAXTER J. D., GELFAND D., TOMKINS G. M., 1975. Binding of glucocorticoid receptors to DNA. J. biol. Chem., 250, 6015-6021.

ROY R. K., LAU A. S., MUNRO H. N., BALIGA B. S., SARKAR S., 1979. Release of in vitrosynthesized poly(A)-containing RNA from isolated rat liver nuclei : characterization of the ribonucleoprotein particles involved. Proc. nat. Acad. Sci. USA, 76, 1751-1755.

ROZEK C. E., DAVIDSON N., 1983. Drosophila has one myosin HC gene with three developmentally regulated transcripts. Cell, 32, 23-34.

SADLER S. E., MALLER J. L., 1982. Identification of a steroid receptor on the surface of Xenopus oocytes by photoaffinity labelling. J. biol. Chem., 257, 355-361.

SALDITT-GEORGIEFF M., HARPOLD M., SAWICKI S., NEVINS J., DARNELL J. E., 1980. Addition of Poly(A) to nuclear RNA occurs soon after RNA synthesis. J. Cell Biol, 86, 844-848.

SANDO J. J., LA FOREST A. C., PRATT W. B., 1979a. ATP-dependent activation of L-cell glucocorticoid receptors of the steroid binding form. J. biol. Chem., 254, 4772-4778.

SANDO J. J., HAMMOND N. D., STRATFORD C. A., PRATT W. B., 1979b. Activation of thymocyte glucocorticoid receptors of the steroid binding form. J. biol. Chem., 254, 4779-4789.

SANO H., SAGER R., 1980. DNA methyltransferase in the eukaryote chlamydomonas reinhardi. Eur. J. Biochem., 105, 471-480.

SATO B., NOMA K., NISHIZAWA Y., NAKAO K., MATSUMOTO K., YAMAMURA Y., 1980. Mechanism of activation of steroid receptors : involvement of low molecular weight inhibitor in activation of androgen, glucocorticoid and estrogen receptor systems. Endocrinology, 106, 1142-1148.

SCHEER U., SOMMERVILLE J., BUSTIN M., 1979. Injected histone antibodies interfere with transcription if lampbrush chromosome loops in oocytes of Pleurode/es. J. Cell Sci., 40, 1-20.

SCHEIDEREIT C., BEATO M., 1984. Contacts between hormone receptor and DNA double helix within a glucocorticoid regulating element of mouse mammary tumor virus. Proc. nat. Acad. Sci. USA, 81, 3029-3033.

SCHMIDT T. J., LITWACK G., 1982. Activation of the glucocorticoid-receptor complex. Physiol. Rev., 62, 1131-1192.

SCHRADER W. T., O'MALLEY B. W., 1978. Molecular structure and analysis of progesterone receptors, 189-224. In O'MALLEY B. W., BIRNBAUMER L., Receptors and hormone action. Acad. Press, New York.

SEREKIS C. E., GUIALIS A., 1981. Low-molecular-weight nuclear ribonucleoprotein particles, 247 259 vol. VIII. In BUSCH H., The cell nucleus, Acad. Press, New York.

SETYONO B., PEDERSON T., 1984. Ribonucleoprotein organization of Eukaryotic RNA. J. mol. Biol., 174, 285-295.

SHERIDAN P. J., BUCHANAN J. M., ANSELMO V. C., MARTIN P. M., 1979. Equilibrium : the intracellular distribution of steroid receptors. Nature, 282, 579-582.

SIMMEN R. C., MEANS A. R., CLARK J. H., 1984. Estrogen modulation of nuclear matrix-associated steroid hormone binding. Endocrinology, 115, 1197-1202.

SINGH V. B., MOUDGIL V. K., 1985. Phosphorylation of rat liver glucocorticoid receptor. J. biol. Chem., 260, 3684-3690.

SMIRNOVA O. V., SMIRNOV A. N., ROSEN V. B., 1977. Multicomponent system of estradiol binding protein in rat liver cytosol. Dependence on sex steroids. Bull. exp. Biol. Med. (USSR), 83. 548-551.

SMIRNOVA O. V., KIZIM E. A., SMIRNOV A. N., NIKOLOV I. T., ROSEN V. B., 1980. Effet of some endocrine factors on the rat liver. Bull. exp. Biol. Med. (USSR), 90, 480-483. 
SOMMERVILLE J., 1981. Immunolocalization and structural organization of nascent RNP, 1-57, vol. VIII. In BUSCH H., The cell nucleus, Acad. Press, New York.

SPELSBERG T. C., HALBERG F., 1980. circannual rythms in steroid receptor concentration and nuclear binding in the chick oviduct. Endocrinology, 107, 1234-1244.

SPELSBERG T. C., LITTLEFIELD B. A., SEELKE R., MARTIN-DANI G., TOYODA H., BOYD-LEINEN P., THRALL C., KON O. L., 1983. Role of specific chromatosomal proteins and DNA sequences in the nuclear binding sites for steroid receptors. Recent Prog. Horm. Res., 39, 463513.

SPELSBERG T. C., GOSSE B. J., LITTLEFIELD B. A., TOYODA H., SEELKE R., 1984. Reconstitution of nativelike nuclear acceptor sites of the avian oviduct progesterone receptor : evidence for involvement of specific chromatin proteins and specific DNA sequences. Biochemistry, 23, 5103-5113.

STALDER J., GROUDINE M., DODGSON J. B., ENGEL J. D., WEINTRAUB H., 1980a. Hb switching in chickens. Cell, 19, 973-980.

STALDER J., LARSEN A., ENGEL J. D., DOLAN M., GROUDINE M., WEINTRAUB H., 1980 b. Activation of globin genes during chicken development. Cell, 20, 451-460.

STORB U., WILSON R., SELSING E., WALFIELD A., 1981. Rearranged and germline immunoglubolin $K$ genes : different states of DNase I sensitivity of constant $K$ genes in immunocompetent and nonimmune cells. Biochemistry, 20, 990-996.

SZEGO C. M., PIETRAS R. J., 1985. Subcellular distribution of oestrogen receptors. Nature, $317,88$.

TAMULEVICIUS P., LAX E. R., MULLER A., SCHRIEFERS H., 1982. Nuclear oestrogen receptors in rat liver. Biochem. J., 206, 279-286.

TANUMA S., JOHNSON L. D., JOHNSON G. S., 1983. Glucocorticoid action and ADP-ribosylation of chromosomal proteins. J. Cell Sci, 157a.

TAYLOR R. N., SMITH R. G., 1982a. Identification of a novel sex steroid binding protein. Proc. nat. Acad. Sci. USA, 79, 1742-1746.

TAYLOR R. N., SMITH R. G., 1982b. Effects of highly purified estrogen receptors on gene transcription in isolated nuclei. Biochemistry, 21, 1781-1787.

TAYLOR R. N., SMITH R. G., 1985. Correlation in isolated nuclei of template-engaged RNA polymerase II, ovalbumin mRNA synthesis, and estrogen receptor concentrations. Biochemistry, 24, 1275-1280.

THAMPAN R. V., 1985. The nuclear binding of estradiol stimulates ribonucleoprotein transport in the rat uterus. J. biol. Chem., 260, 5420-5426.

THOMA F., KOLLER T., KLUG A., 1979. Involvement of histone $H 1$ in the organization of the nucleosome and of the salt-dependent superstructures of charomatin. J. Cell Biol., 83, 403-427.

THOMAS J. O., 1983. Chromatin structure and superstructure, 9-30. In MACLEAN N., GREGORY S. P., FLAVELL R. A., Eukaryotic genes, their structure, activity and, regulation, Butterworths, London.

THOMAS J. O., 1984. The higher order structure of chromatin and histone H1. J. Cell Sci., Suppl. 1. $1-20$

TOYODA H., SEELKE R. W., LITTLEFIELD B. A., SPELSBERG T. C., 1985. Evidence for specific DNA sequences in the nuclear acceptor sites of the avian oviduct progesterone receptor. Proc. nat. Acad. Sci. U. S. A., 82, 4722-4726.

TUBO R. A., SMITH H. C., BEREZNEY R., 1985. The nuclear matrix continues DNA synthesis at in vivo replicational forks. Biochim. Biophvs. Acta, 825, 326-334.

TYMOCZKO J. L., SHAPIRO J., SIMENSTAD D. J., NISH A. D., 1982. The effects of polyribonucleotides on the binding of dexamthasone-receptor complex to DNA. J. Steroid Biochem., 16. 595-598.

TYMOCZKO J. L., PHILLIPS M. M., 1983. The effects of ribonuclease on rat liver dexamethasone receptor: increased affinity for deoxyribonucleic acid and altered sedimentation profile. Endocrinology, 112, 142-149.

VAN EEKELEN C. A. G., VAN VENROOIJ W. J., 1981. HnRNA and its attachement to a nuclear protein matrix. J. Cell Biol., 88, 554-563. 
VAZOUEZ-NIN G. H., ECHEVERRIA O. M., MOLINA E., FRAGOSO J., 1978. Effects of ovariectomy and estradiol injection on nuclear structures of endometrial epithelial cells. Acta anat., 102, 308-318.

VAZOUEZ-NIN G. H., ECHEVERRIA O. M., PEDRON J., 1979. Effects of estradiol on the ribonucleoprotein constituents of the nucleus of cultured endometrial epithelial cells. Biol. Cell, 35, 221-228.

VIDALI G., BOFFA L. C., BRADBURY E. M., ALLFREY V. G., 1978. Butyrate suppression of histone deacetylation leads to accumulation of multiacetylated forms of histone $\mathrm{H} 3$ and $\mathrm{H} 4$ and increased DNase I sensitivity of the associated DNA sequences. Proc. nat. Acad. Sci. USA, 75, 2239-2243.

VLAD M. T., 1983. Lampbrush chromosomes, 85-99. In MACLEAN N., GREGORY S. P., FLAVELL R. A., Eukaryotic Genes, Butterworths, London.

VON HOLT C., STRICKLAND W. N., BRANDT W. F., STRICKLAND M. S., 1979. More histone structures. FEBS Lett., 100, 201-218.

WALTER P., GREEN S., GREENE G., KRUST A., BORNERT J. M., JELTSCH J. M., STAUB A., JENSEN E., SCRACE G., WATERFIELD M., CHAMBON P., 1985. Cloning of the human estrogen receptor cDNA. Proc. nat Acad. Sci. USA, 82, 7889-7893.

WEBB T. E., SCHUMM D. E., PALAYOOR T., 1981. Nucleocytoplasmic tranport of mRNA, 199-248, vol. IX. In BUSCH H., The cell nucleus, Acad. Press, New York.

WEIGEL N. L., TASH J. S., MEANS A. R., SCHRADER W. T., O'MALLEY B. W., 1981. Phosphorylation of hen progesterone receptor by cAMP dependent protein kinase. Biochem. biophys. Res. Commun., 102, 513-519.

WEINBERGER M. J., 1984. Heterogeneity and distribution of estrogen binding sites in guinea pig seminal vesicle. J. Steroid Biochem., 20, 1327-1332.

WEINBERGER C., HOLLENBERG S. M., ONG E. S., HARMON J. M., BROWER S. T., CIDLOWSKI J., THOMPSON E. B., ROSENFELD M. G., EVANS R. M., 1985. Identification of human glucocorticoid receptor complementary DNA clones by epitope selection. Sciences, 228, 740742.

WEINTRAUB H., GROUDINE M., 1976. Chromosomal subunits in active genes have an altered conformation. Science, 193, 848-856.

WEINTRAUB H., LARSEN A., GROUDINE M., 1981. a-Globin gene switching during the development of chicken embryos : expression and chromosome structure. Cell, 24, 333-344.

WEISBROD S., Active chromatin. 1982. Nature, 297, 289-295.

WEISBROD S., WEINTRAUB H., 1979. Isolation of a subclass of nuclear proteins responsible for conferring a DNase I-sensitive structure on globin chromatin. Proc. nat. Acad. Sci. USA, 76, 630-634.

WELSHONS W. V., LIEBERMAN M. E., GORSKI J., 1984. Nuclear localization of unoccupied oestrogen receptors. Nature, 307, 747-749.

WHELLY S. M., BARKER K. L., 1982. Regulation of the peptide elongation reaction on uterine ribosomes by estrogens. J. Steroid Biochem., 16, 495-501.

WILK H. E., WERR H., FRIEDRICH D., KILTZ H. H., SCHAFER K. P., 1985. The core proteins of 35S hnRNP complexes. Eur. J. Biochem., 146, 71-81.

WILKS A. F., COZENS P. J., MATTAJ I., JOST J. P., 1982. Estrogen induces a demethylation at the $5^{\prime}$ end region of the chicken vitellogenin gene. Proc. nat. Acad. Sci. USA, 79, 4252-4255.

WU C., 1980. The $5^{\prime}$ end of drosophila heat shock genes in chromatin are hypersensitive to DNase I. Nature, 286, 854-860.

WU C., 1984a. Two protein-binding sites in chromatin implicated in the activation of heat-shock genes. Nature, 309, 229-234.

WU C., 1984b. Activating protein factor binds in vivo to upstream control sequences in heat shock gene chromatin. Nature, 311, 81-84.

WU R. S., TSAI S., BONNER W. M., 1982a. Patterns of histone variant synthesis can distinguish G0 from G1 cells. Cell, 31, 367-374.

WU R. S., NISHIOKA D., BONNER W. M., 1982b. Differential conservation of histone H2A variants between mammals and sea urchins. J. Cell Biol., 93, 426-431, 
WUNDERLICH F., 1981. Nucleocytoplasmic transport of ribosomal subparticles : interplay with the nuclear envelope, 249-287 vol. IX. In BUSCH H., The cell nucleus, Acad. Press, New York.

WURTZ R., 1985. Events in glucocorticoid hormone action. A correlation of $\mathrm{H} 1$ variant pattern changes, hormone binding to cell nuclei and induction of MMTV RNA. Eur. J. Biochem., 152, 173-178.

YANG V. W., LERNER M., STEITZ J. A., FLINT S. J., 1981. A small nuclear ribonucleoprotein is required for splicing of adenoviral early RNA sequences. Proc. nat. Acad. Sci. USA, 78, 1371-1375.

ZEEVI M., NEVINS J. R., DARNELL J. E., 1982. Newly formed mRNA lacking polyadenylic acid enters the cytoplasm and the polyribosomes but has a shorter half-life in the absence of polyadenylic acid. Mol. cell. Biol., 2, 517-525.

ZIEVE G., PENMAN S., 1981. Subnuclear particles containing a small nuclear RNA and heterogeneous nuclear RNA. J. mol. Biol., 145, 501-523. 